\title{
Tracking Hunter-Gatherer Impact on Vegetation in Last Interglacial and Holocene Europe: Proxies and Challenges
}

\author{
Anastasia Nikulina ${ }^{1}$ (D) Katharine MacDonald ${ }^{1}$ (D) Fulco Scherjon $^{1}$ (D) . \\ Elena A. Pearce ${ }^{2}$ (D) Marco Davoli ${ }^{2}$ (D) . Jens-Christian Svenning ${ }^{(\mathbb{D})}$, et al. [full \\ author details at the end of the article]
}

Accepted: 29 November 2021 / Published online: 1 January 2022

(c) The Author(s) 2021

\begin{abstract}
We review palaeoenvironmental proxies and combinations of these relevant for understanding hunter-gatherer niche construction activities in pre-agricultural Europe. Our approach consists of two steps: (1) identify the possible range of hunter-gatherer impacts on landscapes based on ethnographic studies; (2) evaluate proxies possibly reflecting these impacts for both the Eemian (Last Interglacial, Middle Palaeolithic) and the Early-Middle Holocene (Mesolithic). We found these paleoenvironmental proxies were not able to unequivocally establish clear-cut differences between specific anthropogenic, climatic and megafaunal impacts for either time period in this area. We discuss case studies for both periods and show that published evidence for Mesolithic manipulation of landscapes is based on the interpretation of comparable data as available for the Last Interglacial. If one applies the 'Mesolithic' interpretation schemes to the Neanderthal record, three common niche construction activities can be hypothesised: vegetation burning, plant manipulation and impact on animal species presence and abundance. Our review suggests that as strong a case can be made for a Neanderthal impact on landscapes as for anthropogenic landscape changes during the Mesolithic, even though the Neanderthal evidence comes from only one high-resolution site complex. Further research should include attempts (e.g. by means of modelling studies) to establish whether huntergatherer impact on landscapes played out at a local level only versus at a larger scale during both time periods, while we also need to obtain comparative data on the population sizes of Last Interglacial and Holocene hunter-gatherers, as these are usually inferred to have differed significantly.
\end{abstract}

Keywords Human-environment interaction $\cdot$ Holocene $\cdot$ Mesolithic $\cdot$ Neanderthal Last Interglacial $\cdot$ Hunter-gatherers 


\section{Introduction}

Since the coining of the term Anthropocene for the current human-dominated geological epoch by Crutzen and Stoermer (Crutzen, 2002; Crutzen \& Stoermer, 2000), the starting date for this period, as well as its geological relevance, has been under permanent debate. Suggestions for the beginning of the Anthropocene vary, from $13,800 \mathrm{BP}$ when significant vegetation transformations and megafauna extinctions occurred, to the mid-twentieth century with the introduction of plastics and concrete production (Lewis \& Maslin, 2015; Ruddiman, 2013; Smith \& Zeder, 2013; Waters et al., 2016; Zalasiewicz et al., 2015). The absence of consensus among researchers concerning relevant types of evidence (e.g. greenhouse gases, isotopes caused by nuclear weapons detonations, biosphere modified by species extinctions and invasions, novel human-made 'minerals' such as bricks, ceramic, concrete, asphalt), as well as the need for a 'golden spike' (global boundary stratotype section), greatly complicate defining a starting point for the Anthropocene (Castree, 2017; Zalasiewicz et al., 2019). While the Anthropocene Working Group recently decided to use the stratigraphic signal of global distribution of primary artificial radionuclide signal due to atomic bomb explosions in the mid-twentieth century as the Anthropocene's 'golden spike' (Anthropocene Working Group, 2019; Zalasiewicz et al., 2015), beyond the geological community, broader discussions stimulated by this 'origins debate' still continue.

In the context of the debate about the status and chronology of the Anthropocene, questions about when and how humans began to shape the global earth system, including how human subsistence and land use strategies affected land cover, ecosystems and other aspects of their environments, are identified as priorities for research in archaeology and paleoecology (Ellis et al., 2021; Kintigh et al., 2014; Seddon et al., 2014; Thompson et al., 2021). An early (Pleistocene) date for the Anthropocene seems unjustified, in terms of the scale of human impacts in the Pleistocene past, and, as some hold, because of the ideological implications (Lane, 2015). However, this debate has highlighted the relevance of systematic studies of when humans began to have an impact on their landscapes, the spatial and temporal scale of these effects, and the nature of early impacts on the earth system.

Humans have a long prehistory of niche construction, defined as 'the process whereby organisms, through their metabolism, their activities and their choices, modify their own and/or other species niches' (Odling-Smee et al., 2013). Given this definition, both agriculture and a foraging lifestyle can be considered human niche constructions. It is widely accepted that the emergence of agriculture strongly increased human impact on their environments, compared to that of foraging societies (e.g. Delcourt, 1987; Kirch, 2005; Roberts et al., 2018; Ruddiman, 2013). Agricultural activities tend to replace diverse natural vegetation with relatively few domesticates with highly reduced habitat value for biodiversity, and can thereby increase species extinction rates and alter biogeochemical cycles (Lewis \& Maslin, 2015); this makes the shift to agriculture very relevant to discussions of the origins and the character of the Anthropocene (Lindholm et al., 2020). 
The focus of the current article is, however, on foragers, who also conduct both active and inadvertent niche construction (Smith, 2011). In this paper, hunter-gatherers (foragers) are defined as populations which mainly depend on food collection or foraging of wild resources (Ember, 2020). Foragers can and do actively transform land cover and ecosystems (e.g. Rowley-Conwy \& Layton, 2011; Smith, 2011). In particular, the controlled use of fire, which is an important part of the technological repertoire of more recent forms of Homo (Alperson-Afil, 2017; Dibble et al., 2018; Gowlett \& Wrangham, 2013; Roebroeks \& Villa, 2011; Sandgathe et al., 2011), could have facilitated landscape transformations. Anthropogenic fire could possibly be as significant as or, in later stages, exceeding the impact of natural fires (Scherjon et al., 2015; Thompson et al., 2021; Whelan, 1995; Wrangham, 2009). In addition, Late Pleistocene faunal extinctions, in which human hunting is often implicated (Andermann et al., 2020; Sandom et al., 2014b; Smith et al., 2018), were associated with reduction of the structural diversity of vegetation (e.g. Bakker et al., 2016; Berti \& Svenning, 2020; Sandom et al., 2014a), changed fire regimes and likely a range of other ecosystem processes. Thus, studying hunter-gatherer impact on their surroundings is of interest in terms of anthropogenic ecosystem modifications in forager habitats as well as for contextualising and understanding the scale of Holocene agricultural transformation.

Identifying the possible impact of past hunter-gatherers on their environments to some degree calls for knowledge of 'human free' or 'natural' ecosystems, which arguably suggest the existence of a 'natural palaeoenvironment'. Such a term implies that environments exist in a stable natural state until disrupted by humans. However, all environments are constantly changing, determined by a myriad of factors such as climate, faunal activities, natural fire regimes and hominins. This makes it difficult to discriminate between 'natural' and anthropogenic changes (Schreve, 2019). Nonetheless, the Eemian interglacial, sometimes seen as an analogue for present-natural vegetation (Svenning, 2002), provides an interesting case study in this respect.

The Eemian interglacial (Last Interglacial; 130,000-116,000 BP) is the most recent (before the Holocene or current interglacial) in a series of Pleistocene interglacials - warm-temperate periods between glaciations (Schreve, 2019) - with a climate and vegetation comparable to the Holocene over major parts of Europe (Svenning, 2002). On a finer scale, however, there were differences: the Eemian interglacial witnessed a higher sea level than the Holocene, making for a somewhat more Atlantic climate in western and central Europe than during the Holocene (Zagwijn, 1989). The Late Pleistocene extinction of various larger mammals occurred after the Eemian interglacial, and the absence of specific large herbivores such as elephant and rhinoceros during the Holocene may have decreased overall herbivore impact on vegetation during the current interglacial (Svenning, 2002). Study of Eemian vegetation structure may provide insights into the specific differences between the two interglacial periods and the factors responsible for these differences. At the same time, these differences make it challenging to understand the role of Neanderthal hunter-gatherers in this period.

The disappearance of megafaunal species during the latest Pleistocene and the Holocene was a complicated process that varied from region to region (e.g. Mann et al., 2019; Sandom et al., 2014b; Stewart et al., 2021; Wang et al., 2021), with 
likely overkill by Homo sapiens (Sandom et al., 2014b). Still, Neanderthals' game spectra were very much comparable to those of the first modern humans in Eurasia (Bar-Yosef, 2004; Wißing et al., 2019), and localised extinctions or potential reduction of populations of medium- to large-sized herbivores do seem to correlate to much earlier Pleistocene hominin range expansions (Speth \& Clark, 2006; Staesche, 1983; Surovell et al., 2005). In addition, besides their potential impact on megafauna, Neanderthals are considered to have possibly played a role in vegetation openness around the Last Interglacial Neumark-Nord 2 lake area site (Germany) (Roebroeks et al., in press; Roebroeks \& Bakels, 2015). While Neumark-Nord 2 provides us with an exceptionally high-resolution - but thus far unique - case (see below), it does suggest that Neanderthals elsewhere also could have transformed their surroundings on a local scale, e.g. via burning practices. However, their inferred small population sizes, and the low population densities that these imply, suggest a limited impact.

Despite the problems differentiating between natural and anthropogenic changes in past environments, the quantity of research devoted to pre-industrial human impacts on landscapes is increasing (e.g. Dietze et al., 2018; Hamilton et al., 2019; Thompson et al., 2021), as a result of increasing interest in the role of past humans in landscape transformations and the environmental consequences this may have entailed (e.g. Oldfield \& Dearing, 2003; Thompson et al., 2020). However, specific research on the environmental impact of prehistoric hunter-gatherers is relatively rare, and hampered by both theoretical issues (a tendency to contrast hunter-gatherers and farmers) and methodological ones (Lightfoot et al., 2013). For example, detecting past hunter-gatherer burning of landscapes may be difficult because the effects may be limited at low population densities, and tend to mimic or be completely concealed by natural fire regimes (Scherjon et al., 2015). Scherjon et al. (and comments therein) stress the need for more information combining various proxies, such as charcoal records and molecular markers, from well-sampled and well-dated sequences with archaeological records from the same area (ibid.). Standard requirements regarding the kinds of data that should be collected for such studies are lacking, and there are obvious taphonomic limitations on the range of data that can be collected and documented from prehistoric sites. In this regard, it is important to include a wide variety of relevant methods and proxies suitable for understanding hunter-gatherer impact, evaluate the strengths and weaknesses of various approaches and establish the character of the association between proxies and hunter-gatherer activity: hence this review.

The practice of interpreting past hunter-gatherer impact is best understood with the aid of concrete case studies, presented below, for the Last Interglacial and for the Holocene. The possibility that Mesolithic hunter-gatherers modified their environments has been explored since the late 1960s (Simmons, 1996; Woodburn, 1980; Zvelebil, 1994), and as a result a number of studies of relevant palaeoenvironmental evidence have been published. This possibility has also been considered for Upper Palaeolithic hunter-gatherers of the Last Glacial Maximum (Kaplan et al., 2016), but not, or very rarely, for earlier periods (see Thompson et al., 2021 for such an exceptional case-study from Lake Malawi, Africa). However, at least one Middle Palaeolithic case study seems to provide high-resolution evidence minimally indicative of 
Neanderthal impact on the local vegetation (Roebroeks et al., in press; Roebroeks \& Bakels, 2015).

The aims of this paper are twofold: (1) to present the variety of available proxies relevant for studying past hunter-gatherer environmental impacts, and (2) to examine the presence and usefulness of the various types of evidence within specific geographical and chronological settings. The structure of the article is the following: (1) first we describe hunter-gatherer niche construction activities based on ethnographic observations; (2) we then list and evaluate proxies for each category of niche construction activity; (3) we illustrate the use of proxies in Middle Palaeolithic (Neanderthal) and Mesolithic archaeological contexts dating to the Last Interglacial ( 130,000-116,000 BP) and Early-Middle Holocene ( 11,700-6,000 BP) respectively; (4) finally, we discuss the validity of current understanding of Neanderthal and Mesolithic hunter-gatherer impact on warm-temperate landscapes.

\section{Ethnographic Observations of Hunter-Gatherer Impact on Landscapes}

Ethnographic records constitute an important source for understanding relationships between (sub-)recent hunter-gatherers and their environments and can help to build solid inferences about the possible antiquity of such relationships. However, we do need to acknowledge that the application of ethnographic data in this way faces important limitations: firstly, it is likely that only a small part of past diversity in foraging subsistence activities is reflected in the record of (sub-)recent hunter-gatherers (Bettinger, 2001). Secondly, it is clear that many (sub-)recent hunter-gatherers were part of larger socio-economic systems in which hunter-gatherer subsistence strategies were influenced by trade and communication across different regions, sometimes on a worldwide scale, as seen in the example of western European demand for South African bush products which directly impacted local hunter-gatherer hunting there (e.g. Stiles, 1992, 2001; Wolf, 2010). Thirdly, geographical biases and timelimited observations restrict the scope of ethnographic records (Scherjon et al., 2015; Smith et al., 2013). While an attempt has been made here to include a wide range of geographical and temporal ethnographic contexts, this only partially addresses these limitations. One of the reasons is geographical bias, with hunter-gatherers having disappeared from temperate parts of the world such as Europe, the region at stake here, long before ethnographic or ethnohistoric documentation started. Nevertheless, ethnographic data helps in interpreting decision-making behaviour leading to the creation of the archaeological record as well as the roles which ecological, biological, social and cultural settings play in these processes (Kelly, 2013).

The categories of hunter-gatherer niche construction practices listed below are not intended to cover the whole range of foraging and resource procurement activities in detail: these general categories were identified to illustrate possible ways in which hunter-gatherer activities can lead to landscape transformations and to structure the discussion of ethnographically documented niche construction and the relevant archaeological proxies. Based on review papers on ethnographic data (Rowley-Conwy \& Layton, 2011; Smith, 2011), we identified the following categories 
for hunter-gatherer niche construction and effects on landscapes, to be discussed below: (1) modification of vegetation communities via burning; (2) small-scale plant manipulation; (3) landscape modification to impact animal presence and their abundance at specific locations.

Human-induced burning of vegetation communities, the first category, was a common practice which has been documented in all vegetation types except tundra (Scherjon et al., 2015), and with more cases for hunter-gatherers occupying forested or shrubland areas (Mellars, 1976). The ecological consequences of these practices are determined by the intensity, seasonality and frequency of burning and the fire resilience of plants, and mainly include improving the qualities and quantities of forage from a hunter-gatherer point of view (ibid.; Anderson, 2005). Burning activities are often carried out for short-term purposes (e.g. hunting) but their repetitive character can have major long-term consequences, such as the creation of mosaic vegetation, with increase of biodiversity and reduced risk of habitat loss. Such an approach transforms an occupation area into a mosaic with diverse foraging and hunting options for humans at a relatively small spatial scale (Anderson, 2005; Bird et al., 2008).

The second category is small-scale plant manipulation, which does not imply plant domestication and cultivation of domesticated plants in a broad agricultural sense (involving human intervention becoming essential for replanting and the plant food making a large contribution to human diet). This category rather includes several smaller-scale activities such as broadcasting of wild annuals' seeds, and transplantation and in-place encouragement of fruit/nut-bearing species, plants that can be harvested for raw materials and perennial root crops via pruning, coppicing, thinning, clearing, weeding or fertilising (Feeney, 2019; Smith, 2011). While these actions can modify vegetation, it is often difficult to track which of these specific activities was carried out by hunter-gatherers in the deep past. Potentially, transformation of existing communities via these actions may be reflected in genetic transformations of some cultivated species (e.g. size of seeds, thickness of seed coats) (Greaves \& Kramer, 2014; Rowley-Conwy \& Layton, 2011; Smith, 2011).

In contrast to these strategies that encourage growth, trees may be killed to ensure firewood supplies, with implications for vegetation cover (Henry et al., 2008; Pryor et al., 2016). Construction of habitat improvement features (e.g. canals and dams, soil retention walls) has also been documented as a part of foragers' plant manipulation strategies, e.g. for Northern American hunter-gatherers (Anderson, 2005; Harrower, 2016). Other examples come from Australia where indigenous populations constructed small-scale water diversions, impoundments and dams (Jackson $\&$ Barber, 2016). Construction of such features can potentially leave more visible traces than small-scale activities involving plant transplantation, sowing or in-place encouragement.

The third category of hunter-gatherer niche construction consists of enhancing and/or expanding the geographic range of specific animal species and the management of prey movements. These activities can include the construction of 'clam gardens', fish weirs and traps, the transformation of fish streams via removing debris and translocation of fish eggs, and the use of fences to control herbivore movements (Rowley-Conwy \& Layton, 2011; Smith, 2011). These types of resource 
manipulation have been documented ethnographically in various regions, particularly in North and Central America, Siberia, Africa and Australia (e.g. Anderson et al., 2019; Campbell \& Butler, 2010; Deur et al., 2015; Khomich, 1966; McKey et al., 2016; Pascoe, 2014).

Controlled burning is also a tool for prey management. In particular, fire was used to drive animals and fish towards a specific location or temporarily paralyse prey to make hunting or fishing easier (Lytwyn, 2001; Roos et al., 2018; Scherjon et al., 2015). Recently burned areas are attractive for many herbivores because the increased visibility makes it easier to avoid predators and the new vegetation cover contains a higher nutrient level; these freshly burned areas also support hunting opportunities for some birds and insects (e.g. Allred et al., 2011; Bird et al., 2008; Eby et al., 2014; Herzog et al., 2016; Komarek, 1969; Mellars, 1976; Reid, 2012). People were then able to hunt prey animals attracted to recently burned areas (Scherjon et al., 2015). In addition, smoke from fireplaces around camps can provide animals such as reindeer with relief from biting insects, leading them to congregate within specific locations in the open air or inside specially constructed buildings (Groß et al., 2019).

Thus, hunter-gatherer subsistence strategies include a diverse set of niche construction activities, which allows foragers to be flexible, adaptable and able to withstand change and which also debunk characterisations of these populations as passive consumers of natural resources (Hitchcock, 2019; Kelly, 2013; Smith et al., 2013). While these activities could increase the local abundance of the plant and animal resources on which hunter-gatherers rely, these and other foraging and hunting activities could also depress resources (Feeney, 2019). We do not assume that all Pleistocene and Holocene groups of foragers engaged in all the types of activity described here in their daily practices. In addition, there is no consensus about which specific practices were incorporated in Neanderthal and Mesolithic strategies or differences/similarities between the niche construction activities of these two populations. To compare hominin impact on landscapes in these two periods, and begin to understand differences and similarities, we need to take the full range of possible activities into account. Therefore, the next section is devoted to the presentation and evaluation of proxies for each type of niche construction activity.

\section{Types of Evidence Related to Past Hunter-Gatherer Niche Construction Activities}

The following sections ("Proxies for Identification of Modification of Vegetation Communities Via Burning", "Proxies for Identification of Small-Scale Plant Manipulation by Hunter-Gatherers" and "Proxies for Landscape Modifications to Impact Animal Presence and Their Abundance in Specific Locations") are devoted to a review of proxies which correspond to three categories of hunter-gatherer impact defined on the basis of ethnographic studies ("Ethnographic Observations of HunterGatherer Impact on Landscapes" section). Tables 1, 2, and 3 reflect the availability of different proxies in relation to their spatial scale (i.e. which scale is reflected in a specific type of evidence) and for the two time periods (the Last Interglacial and 
Table 1 Proxies and their maximum possible temporal representation (availability) and spatial scale (scale which is reflected in specific type of proxy) for reconstruction of burning of vegetation communities by hunter-gatherers (category 1)

\begin{tabular}{|c|c|c|c|c|c|}
\hline \multirow[t]{2}{*}{ Proxies } & \multicolumn{2}{|l|}{ Temporal scales } & \multicolumn{3}{|c|}{ Spatial scales } \\
\hline & Last Interglacial & $\begin{array}{l}\text { Early-Middle } \\
\text { Holocene }\end{array}$ & Local & Regional & (Sub-)continental \\
\hline Pollen indicators & 0 & & & & ○* \\
\hline AP/NAP & 0 & & & & ○* \\
\hline Charcoal & 0 & & & & ○* \\
\hline NPP & & & & $\mathrm{O}$ & $\mathrm{O}$ \\
\hline Plant macrofossils & 0 & & & 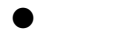 & $\bigcirc$ \\
\hline DNA from sediments & & & & & $\bigcirc$ \\
\hline Phytolith data & & & & 0 & O \\
\hline PAHs & & & & & 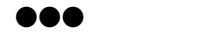 \\
\hline Black carbon & ○ & & & & \\
\hline Levoglucosan & 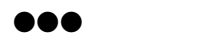 & & O & & 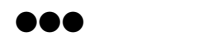 \\
\hline
\end{tabular}

*this spatial scale can be reached via integration of data from multiple sites

$\bigcirc$ - absence of proxies

- low availability/spatial resolution

- average availability/spatial resolution

○० - high availability/spatial resolution

Table 2 Proxies and their maximum possible temporal representation (availability) and spatial scale (scale which is reflected in specific type of proxy) for reconstruction of plant manipulation organised by hunter-gatherers (category 2)

\begin{tabular}{|c|c|c|c|c|c|}
\hline \multirow[t]{2}{*}{ Proxies } & \multicolumn{2}{|l|}{ Temporal scales } & \multicolumn{3}{|c|}{ Spatial scales } \\
\hline & Last Interglacial & $\begin{array}{l}\text { Early-Middle } \\
\text { Holocene }\end{array}$ & Local & Regional & (Sub-)continental \\
\hline Tools for plant manipulation & O & & & 0 & O \\
\hline Plant macrofossils & 0 & & & 0 & $\bigcirc$ \\
\hline Pollen indicators & 0 & & & 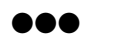 & O \\
\hline Phytolith data & 00 & & & 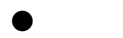 & ○ \\
\hline Parenchyma analysis & O & & & 0 & O \\
\hline Starch-grain analysis & 0 & & & O & $\bigcirc$ \\
\hline
\end{tabular}

- absence of proxies

- low availability/spatial resolution

- average availability/spatial resolution

- high availability/spatial resolution

the Early-Middle Holocene). The local spatial scale is the most detailed, and this scale means that a proxy can be used to identify foragers' niche construction activities at a site and in close proximity to the site. The regional scale corresponds to a 
Table 3 Proxies and their maximum possible temporal representation (availability) and spatial scale (scale which is reflected in a specific type of proxy) for identification of landscape changes to impact animal presence and their accessibility in specific locations (category 3 )

\begin{tabular}{|c|c|c|c|c|}
\hline \multirow[t]{2}{*}{ Proxies } & \multicolumn{2}{|l|}{ Temporal scales } & \multicolumn{2}{|l|}{ Spatial scales } \\
\hline & Last Interglacial & $\begin{array}{l}\text { Early- } \\
\text { Middle } \\
\text { Holocene }\end{array}$ & Local Regional & (Sub-)continental \\
\hline Fishing and hunting constructions & $\bigcirc$ & & 0 & $\bigcirc$ \\
\hline Pollen indicators & 0 & & ح & $\bigcirc$ \\
\hline AP/NAP & 0 & & D & $\bigcirc$ \\
\hline NPP & 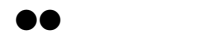 & & 0 & $\bigcirc$ \\
\hline DNA & 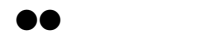 & & 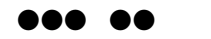 & $\bigcirc$ \\
\hline Stable isotopes & 0 & & 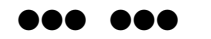 & \\
\hline Zooarchaeological data & 0 & & 0 & O \\
\hline
\end{tabular}

wider area, and this spatial scale can reflect processes around several sites within one region. The (sub-)continental level is the most general level of analysis, and this level corresponds to proxies which reflect processes taking place at the scale of a large subcontinental area or a continent. It is furthermore important to highlight that taphonomic processes as well as research strategies can cause under- or overrepresentation and absence of proxies.

Records from marine cores are often used in studies devoted to environmental changes through Pleistocene time (Kotthoff et al., 2011; Martín-Puertas et al., 2010). However, in virtually all cases, the transformation of landscapes by hunter-gatherers did not trigger visible changes in proxies documented in marine sediments, such as charcoal concentrations in deep sea or off-shore cores (Daniau et al., 2009; Scherjon et al., 2015). Therefore, marine cores are not included in this review, only inland proxies are considered. It is also important to note that identification of human impact on landscapes is only possible when a clear correlation between hominin activities and proxies reflecting landscape changes can be established. In other words, in cases where we have several types of evidence for vegetation openness but where hominin presence could not be clearly identified, these events of vegetation transformation cannot be linked with anthropogenic impact. 


\section{Proxies for Identification of Modification of Vegetation Communities via Burning}

\section{Biological Indicators}

To clarify the transformation of vegetation cover, relative or absolute abundances of remains from plants are required (Birks \& Birks, 2016), and these can be obtained from palynological studies, analysis of non-pollen palynomorphs (NPP), plant macrofossils, DNA from sediments and phytoliths. Although pollen analysis is an important tool in research devoted to human-environment interactions, palynological data has thus far mainly been used to identify agricultural impact on past landscapes (Ledger, 2018), i.e. primarily crop cultivation and cattle grazing. Two major approaches have been used to identify these activities: the indicator species and the comparative approaches (Gaillard, 2013). These rely on the assumption that the ecological preferences of plants were the same in the past as at present or in recent times. The indicator species approach uses a number of pollen taxa (plant species, genus, groups of species or genus, families) that are related to anthropogenic activities such as agriculture (e.g. Behre, 1981; Gaillard, 2013). Occurrence and changes in the amount of these pollen indicators can be related to human impact, i.e. occurrence and changes in the extent of cultivated, hay meadow and/or grazing lands. Gaillard (2013) provides a list of tree and herb pollen taxa (with a few fern spores often included in pollen analyses) grouped into land-use/land-cover types. However, the number and proportions of pollen indicators also depend on the pollen productivity and dispersion characteristics of each plant taxon, the location of human activities in relation to the pollen site, and the type and size of the pollen site (e.g. Hellman et al., 2009; Hicks, 1992; Hicks \& Birks, 1996). The comparative approach builds upon databases of modern pollen assemblages from traditional agricultural landscapes and compares them with fossil assemblages (e.g. Gaillard et al., 1994; Mazier et al., 2006, 2009). For instance, the indicator species approach has been applied within Britain and Ireland to infer Mesolithic forest manipulation, including identification of secondary woodland taxa following disturbance (Warren et al., 2014) and open ground indicators (ibid.; Bishop et al., 2015). Interpretation of such pollen evidence generally relies on the context of certain pollen assemblage and several lines of evidence within the pollen record, including decreases of tree taxa characteristic of mature woodland followed by sudden, regular occurrence or increases of pollen from other tree taxa and woodland herbs favoured by clearance during a short period. To the best of our knowledge, the comparative approach has not been used in studies of hunter-gatherers.

Deforestation and increases in landscape openness can be reconstructed from the relationship between the percentages of arboreal and non-arboreal pollen taxa (AP/NAP). This index is traditionally used to infer changes in landscape openness over time around a pollen site. Inferences about a human role in creating vegetation openness by burning are based primarily on correlation of AP/NAP ratios with evidence for human activity, the presence of proxies indicating burning and evidence for other factors (e.g. natural fire regime, megafauna activity). It has been shown, however, that this relationship is not straightforward and is strongly influenced by the character of the pollen assemblage, i.e. the composition and distribution of 
vegetation patches, the type and size of the pollen site (lake or bog, large or small) and inter-taxonomic differences in pollen productivity and dispersal characteristics (e.g. Sugita et al., 1999; Sugita, 2007a, b; Cui et al., 2013; Hellman et al., 2009). Nevertheless, the combination of AP/NAP percentages with pollen indicators and other palaeoecological data can provide robust reconstructions (e.g. Svenning, 2002). Recent developments in quantitative reconstructions of past plant cover make it possible to provide more realistic reconstructions of past landscape openness at both local and regional spatial scale using the Landscape Reconstruction Algorithm modelling approach (LRA, Sugita, 2007a, b). Among the pollen analytical methods reviewed above, the indicator species approach and the LRA are the most appropriate to identify possible forager activities such as small-scale crop cultivation, use of wild plants for consumption or building material and utensils (e.g. Gaillard, 2013; Gaillard et al., 1994; Regnell et al., 1995), and reconstruct landscape transformations such as changes in regional and local vegetation openness and composition (e.g. Nielsen et al., 2012; Nielsen \& Odgaard, 2010; Trondman et al., 2015).

An important proxy for reconstructing hunter-gatherer burning of vegetation is the concentration of carbonised remains in samples derived from archaeological sites and their surroundings. Although evidence of the use of fire is rare for huntergatherers and less evidence is available for the Palaeolithic than for the Mesolithic (Goldberg et al., 2017), an increased amount of charcoal above a baseline level (i.e. reference level relative to which higher/lower charcoal concentrations are identified) is often considered an indication of human impact (Ledger, 2018). Distinguishing anthropogenic burning is easiest in contexts where vegetation is not prone to burning and natural charcoal production is low (Scherjon et al., 2015). Correlation with proxies indicating vegetation change and human activity is also key. Charcoal particles can travel distances varying from local to regional, with the distance influenced by particle size and shape, characteristics of the fire and wind speed (Vachula et al., 2018; Vachula \& Richter, 2018). However, hunter-gatherer burning is most likely to be detectable on a relatively small scale, particularly when population densities are low (Scherjon et al., 2015), and there are benefits to focusing on charcoal from depositional contexts (such as small lakes or colluvial settings) that reflect this scale. While both microscopic and macroscopic charcoal are of interest, the former is less often available/recorded: in the rest of this article, we do not distinguish the two size classes.

Charcoal records extend back to the Carboniferous period (Scott, 2000) and should be available equally for Palaeolithic and Mesolithic contexts. In interpreting charcoal peaks, it is important to take into account non-anthropogenic factors that affect abundance: fire characteristics, environment, meteorological conditions, taphonomy (e.g. sediment mixing, bioturbation) and time gaps between a fire episode and charcoal deposition (Duffin et al., 2008; Innes et al., 2004). The size of charcoal particles is also influenced by the $\mathrm{pH}$ of their encasing matrix: alkaline sediments lead to fragmentation (Braadbaart et al., 2009). Thus, interpretation of charcoal data in terms of anthropogenic factors is very problematic and any analysis should take into account the many factors related to the specific area, sampling site and methods used. In our analyses, we focus on charcoal data from contexts 
with a local-scale catchment, slow deposition rate, solid chronology and evidence of human activity-related proxies.

Percentages of non-pollen palynomorphs (NPP, e.g. fungi, zoological remains, plant fragments, algae) reflect the local ecological features of a site, because NPP are dispersed locally around the point of their origin (Cugny et al., 2010; Innes et al., 2013; Menozzi et al., 2010). NPP can be preserved in Pleistocene (e.g. Bakels, 2012; Sandom et al., 2014a) and Holocene (e.g. Ryan \& Blackford, 2010; Tunno $\&$ Mensing, 2017) deposits within all types of habitats. This makes NPP applicable for Middle Palaeolithic and Mesolithic studies. NPP provide information about human-driven and natural processes (e.g. erosion, fire frequency, presence of pastures) (Gelorini et al., 2012; Haas, 2010; Revelles \& van Geel, 2016). In particular, the presence of some types of NPP, which appear after fires or can live within open habitats (e.g. Loughlin et al., 2018), constitutes one possible type of evidence of past fires.

Plant macroremains can be seen by the naked eye and identified under a microscope: diaspores (seeds, fruits, some large spores) and vegetative parts such as needles, leaves, buds, budscales, flowers, bulbils and roots. Plants with low pollen production or vegetative reproduction can often be identified through plant macroremain analysis (e.g. Birks, 2001). These remains often indicate local processes when working with autochthonous assemblages from peat bogs and mires, with potential for more regional reconstructions based on allochthonous assemblages in specific environmental settings (fluvial and lacustrine deposits) when transportation is taken into account (Greenwood, 1991; Rawlence et al., 2014). Plant macroremains could be indicative of hunter-gatherer burning when they are charred, derived from open areas (i.e. are left by light demanding species) and/or from nutrient-rich, disturbed areas (i.e. are left by species that grow in burned areas), and if this type of proxy can be correlated with the presence of hunter-gatherers in the study area (Bos \& Urz, 2003).

DNA from sediments is another type of proxy that can be used in studies of anthropogenic burning. DNA can be extracted from different contexts such as frozen soils, marine and lake deposits, peats, loess and archaeological sites. Biodiversity changes, vegetation alteration and climatic fluctuations can be clarified based on extracted DNA from sediments (e.g. Dussex et al., 2021; Giguet-Covex et al., 2014, 2019; Parducci et al., 2012; Rawlence et al., 2014). The current temporal limit of ancient DNA (aDNA) is up to 1 mya for samples from ice and permafrost (Callaway, 2021). ADNA generally comes from plants and animals which were physically present at or near the sampling location and therefore reflect a local signal. However, regional processes such as long-distance dispersal of pollen can also affect results. Depending on the taxon of a plant identified via aDNA, corrections should be made in accordance with information about the pollen productivity of this taxon and longdistance dispersal. Currently, anthropogenic vegetation changes visible via aDNA have mainly been identified for past farming societies and their impact on landscapes via burning, logging and grazing (Dussex et al., 2021; Foster et al., 2020). ADNA allows one to identify plants to a high taxonomic resolution, and this approach is useful for small-scale vegetation changes (Niemeyer et al., 2017). Therefore, sedimentary aDNA could be useful in studies devoted to hunter-gatherer fire events. 
Phytoliths are rigid, microscopic structures made of silica, present in some plant tissues and persisting after the decay of the plant. Although their production depends on taxa, phytoliths occur in many plants, especially grasses, sedges and palms (Albert \& Cabanes, 2007). Phytoliths often represent stable plant remains which decayed in place, reflecting local processes (Rovner, 2001). However, phytoliths can be transported via wind or water, and it is important to decide which of those present were formed in situ (Twiss, 2001). Phytolith analysis is often used in studies of farming societies (e.g. Piperno et al., 2009; Rosen \& Weiner, 1994; Zhang et al., 2010) especially when it is not possible to identify cereals via pollen. Regarding hunter-gatherer impact on landscapes via fire, phytoliths are a tool to study vegetation openness, fire fuel and past burning regimes (Strömberg et al., 2018; Thompson et al., 2021). The inorganic nature of phytoliths makes them resistant to most types of impact including burning and suitable for identification of plants to taxonomic and anatomical levels (Esteban et al., 2018), even though diagenesis can influence preservation of phytolith morphology and hence limit identification, especially in alkaline settings (Braadbaart et al., 2020). Phytoliths have been used in studies devoted to fuel from fireplaces within foragers' sites (e.g. Albert \& Cabanes, 2007; Esteban et al., 2018) and to burning of vegetation (e.g. Boyd, 2002; Roos et al., 2018) by hunter-gatherers.

\section{Geochemical Indicators}

Past fire activity can be estimated via several geochemical proxies. It has been suggested that concentrations of polycyclic aromatic hydrocarbons (PAHs) in sediments reflect past fire activity (Brittingham et al., 2019). Differences between light (3-4 rings) and heavy (5-6 rings) PAHs can be used to separate the background signal from localised burning events. The limitation of this method is instrumental because detecting PAHs requires great sensitivity (Denis et al., 2012). Identification of PAHs has not become a standard research method in studies about hunter-gatherer impact on landscapes: a rare example of application focused on hominin burning during the Middle Palaeolithic (Brittingham et al., 2019).

Black carbon is a fire residue produced by incomplete combustion of organic matter (Brodowski et al., 2005; Kaal, Martinez-Cortizas, et al., 2008b). Black carbon has been used as a proxy for Holocene fire regimes and vegetation reconstruction in palaeoenvironmental and archaeological studies (ibid.; Kaal, et al., 2008a, 2011). Moreover, black carbon appears to be much more abundant in soils and sediments than macroscopic charcoal (Kaal et al., 2008a). Concentrations of black carbon reflect local anthropogenic activities (e.g. cooking, heating) and regional natural processes (e.g. long-distance emissions carried by winds and rainfall) (Ramachandran \& Kedia, 2010; Chen et al., 2018). Therefore, interpretation of black carbon concentrations in sediments can be difficult. Potentially, black carbon can be used in studies about hunter-gatherer burning during the Holocene, but links between burning events on different scales and black carbon concentrations should be supported by data from other proxies.

Levoglucosan is a degradation product obtained from cellulose burning at temperatures more than $300^{\circ} \mathrm{C}$ (Kehrwald et al., 2012). Levoglucosan and its isomers, 
mannosan and galactosan, are considered robust indicators for biomass burning, because they can remain stable in the atmosphere for several days and can be transported over hundreds of kilometres (ibid.; Sang et al., 2016; Schreuder et al., 2019). Levoglucosan then returns to the surface and becomes trapped in continental archives such as ice sheets (Kehrwald et al., 2012). Therefore, levoglucosan reflects regional and continental processes, rather than local-scale fire events such as huntergatherer burning practices.

In summary, burning of vegetation communities by hunter-gatherers can be identified via several types of proxies. All biological indicators (Table 1) reflect fire episodes on the local scale, and some of them do so on the regional scale. This makes biological indicators suitable for studies of hunter-gatherer vegetation burning, because these events were conducted on local scales, and, therefore, may be visible via proxies with a local resolution. Geochemical data is either difficult to detect or can reflect events on all three scales from local to (sub-)continental. Therefore, hunter-gatherer impact on vegetation can be difficult to identify via this group of proxies.

\section{Proxies for Identification of Small-Scale Plant Manipulation by Hunter-Gatherers}

\section{Tools as Indicators of Plant Manipulation}

Discoveries of tools unambiguously related to plant manipulation during the Pleistocene are very rare. Recent studies provided indirect evidence of such activities by hunter-gatherers from Ohalo II (Israel), at about 23,000 years ago: the earliest sickle blades for harvesting of cereals and proto-weeds (Snir et al., 2015). Combinations of different types of proxies (plant macrofossils and tools for plant processing) make this case study relatively unambiguous. While Neanderthals have been shown to be consumers of plant foods (e.g. Henry et al., 2011, 2014), stone tools interpreted as grinding stones are known from a number of Eurasian Upper Palaeolithic sites and suggest systematic exploitation of plant foods including grasses and tubers (Liu et al., 2013; Mariotti Lippi et al., 2015; Revedin et al., 2010).

In accordance with available data, hunter-gatherers included controlled, regular and intensive use of plant resources in their activities by the Late Mesolithic in Europe (Divišová \& Š́́da, 2015), and even small-scale harvesting repeated over many episodes and distributed over a landscape could cause landscape changes. Plant manipulations can be identified via the presence of tools for soil-working, reaping and processing: digging sticks, hoes, mattocks and other tools for procuring roots and tubers, clearing undergrowth, preparing the soil for planting and seeding, and grating/grinding plants (Zvelebil, 1994). Tools can be studied via use-wear analysis, and identified traces on surfaces can show that some tools were used on both plant and animal materials (e.g. Solheim et al., 2018), and some only on plants (e.g. Osipowicz, 2019). Evidence of surface transformation (e.g. ditches, channels) within sites can also reflect plant manipulations organised by foragers (Denham et al., 2004). 


\section{Biological Indicators of Plant Manipulation}

Biological indicators such as plant macroremains and microfossils (pollen, parenchyma, phytoliths and starch grains) do not necessarily represent plant manipulation. The presence of taxa outside their natural environment (i.e. archaeological sites can contain plant remains which were not local in the region where the site is located), overrepresentation of taxa, fragmentation of plants, their carbonisation and spatial distribution of remains within archaeological sites can help to clarify which species were available for hominins, and which plants were used (Divišová \& Šída, 2015). In particular, analysis of plant macroremains from cultural layers shows important plant food resources for hunter-gatherers (e.g. ibid.; Divišová \& Šída, 2015; Regnell, 2012). In addition to macroremains, pollen spectra can also reflect which plants were available for populations (e.g. Finsinger et al., 2006; Regnell, 2012). However, plant macroremains and pollen data do not indicate whether specific forms of manipulation were involved.

Phytoliths were mentioned above in relation to studies of hunter-gatherer impact on vegetation via burning. They are mainly used in studies of plant domestication and cultivation, because of morphological differences between phytoliths of domesticated and wild species (Piperno \& Stothert, 2003; Zeder et al., 2006). The abundance of phytoliths in many plants (Albert \& Cabanes, 2007) could make this proxy useful in studies of hunter-gatherer plant use, but there are currently much fewer studies of phytoliths for hunter-gatherer (e.g. Zurro et al., 2009) than for farming societies.

Parenchyma analysis examines tissue and individual cells of parenchymatous storage organs (Harris, 2013) and reflects local activities of populations (Fuller \& Lucas, 2014). The parenchyma is a part of plant tissue found in most non-woody plants (Pryor et al., 2013). Due to variability in both morphology and physiology, it is possible to identify the plant species and determine if the plant was wild, domesticated or somewhere in between (Morris et al., 2016). Nevertheless, parenchyma cells are often difficult to recognise and can be misinterpreted as burned cells from woody plants. If the parenchyma cells are recovered from a hearth, they may represent plant foods, but they may also have entered the record through animal dung burned as fuel (Pryor et al., 2013). Parenchyma has been recovered from Mesolithic and Epipalaeolithic contexts and some Upper Palaeolithic sites (e.g. Dolní Věstonice II) (ibid.). Their absence from earlier contexts may be related to the relatively recent archaeological use of this proxy (Fuller \& Lucas, 2014). Regarding Mesolithic populations, parenchyma analysis has made it possible to identify categories of available plant food such as Polygonum (buckwheat and knotweed family), Sagittaria el. sagittifolia (arrowhead) from Całowanie (Poland) and roots of dicotyledon plants from Halsskov (Denmark) (e.g. Kubiak-Martens, 1996, 2002).

Starch-grain analysis studies have found organic residue preserved on stone tools (Harris, 2013; Piperno et al., 2004; Pryor et al., 2013) and in dental calculus (Henry et al., 2011; Pryor et al., 2013). These grains are plant microremains such as spores, pollen and phytoliths (Kovárník \& Beneš, 2018). Starch grains are particularly significant because they can be found in all plants and are resistant to grinding and drying, can occasionally survive carbonisation (Cortella \& Pochettino, 1994) and can 
thus provide a list of species used at an archaeological site (Messner et al., 2008). However, starch grains are rarely present (or recovered) from archaeological sites, and often unidentifiable if deteriorated or fragmented (Cortella \& Pochettino, 1994). Starch grains have been identified in the dental calculus of Lower Palaeolithic hominins, with the oldest starch grains identified thus far, from the Sima del Elefante site at Atapuerca, Spain, being 1.2 Ma old (Hardy et al., 2017). More evidence is known from the Middle Palaeolithic, from sites such as Qesem Cave, Israel (Hardy et al., 2016); Shanidar Cave, Iraq; and Spy Cave, Belgium (Henry et al., 2011, 2014). Plant food was an essential dietary component for the occupants of these sites, and indications of heat modification, probably by boiling, of starch grains were identified in Neanderthal dental calculus at Shanidar (Henry et al., 2011, 2014). More details about plant procurement have been obtained for Upper Palaeolithic sites. Analysis of grinding tools from Grotta Paglicci (Italy) showed that humans consumed Avena (oats) and conducted thermal treatment before grinding. Data from Bilancino (Italy) and Dolní Věstonice (Czech Republic) supported evidence of advanced plant exploitation before the agricultural transition in Europe. In relation to the Mesolithic, starch-grain analysis made it possible to identify consumption of domestic cereals (Triticum monococcum, Triticum dicoccum, Hordeum distichon) before 8,550 BP in the Balkans (site of Vlasac) (Kovárník \& Beneš, 2018).

Thus, specific types of plant manipulation by hunter-gatherers can be identified based on specific tools for these activities. The majority of biological proxies only reflect which plants were available, and which species were consumed. Specific types of manipulation are often not possible to identify based on biological indicators alone.

\section{Proxies for Landscape Modifications to Impact Animal Presence and Their Abundance in Specific Locations}

The earliest archaeological evidence of fishing and hunting constructions are dated to the Early-Middle Holocene (e.g. Bailey et al., 2020; Lozovski et al., 2013; McQuade \& O’Donnell, 2007; O'Shea \& Meadows, 2009). Direct evidence of fishing is rare and fragmentary for the Mesolithic in comparison with later periods, and the best sources of information are sites with high moisture content. Fishing structures (fish fences, weirs, screens, traps) were used in specific types of fishing without active human participation (Lozovski et al., 2013; Lozovski \& Lozovskaya, 2016) and served as a barrier to fish migration (Montgomery et al., 2015).

Almost no Mesolithic hunting fences have been discovered, but there are stone structures from the Great Lakes of North America (O'Shea \& Meadows, 2009) and in the southeastern part of Jordan (al Khasawneh et al., 2019), likely dating to the Early Holocene. The low number of hunting fences discovered may be caused by their poor preservation, and dating difficulties as well as limited usage of such constructions by prehistoric hunter-gatherers and incorrect interpretations. Therefore, other evidence should be used to identify hunter-gatherer impact on animal presence and their abundance in specific locations. In particular, it can be identified via data related to changes in megafaunal populations due to overhunting, transportation of 
animals or other factors, which can however be difficult to rule out (e.g. climatic fluctuations). A decrease in the number of herbivores causes changes in vegetation cover such as distribution of shrubs and forests, higher absorption of solar radiation and rises in temperature (Boivin et al., 2016). To detect megafaunal presence and to assess changes in their distribution and density, pollen spectra, NPP, DNA, stable isotopes, and the amount and spatial distribution of faunal remains in layers within archaeological sites should be used as proxies.

As mentioned above ("Proxies for Identification of Modification of Vegetation Communities via Burning" section), changes in the amount of pollen indicators can be related to changes in the extent of grazing land. Increasing percentages of NAP relative to AP reflect increases in landscape openness. Pollen indicators and AP/ NAP should be used together, and their quantitative changes can be caused by several factors including megafaunal presence. In addition to changes in pollen spectra, animal presence can be identified via NPP (coprophilous fungi, eggs of parasites and beetles). These are deposited close to their point of origin (Cugny et al., 2010; Innes et al., 2013; Sandom et al. 2014a; Revelles \& van Geel, 2016; Huang et al., 2020). Both pollen data and NPP have been used to identify the role of herbivores in landscape transformations, past mammalian behaviour and herbivore extinction processes in the past (Gill et al., 2013; Sandom et al. 2014a; Loughlin et al., 2018).

Another proxy for assessing animal presence is DNA. It can be used to understand human actions aimed at enhancing and/or expanding the geographic range of specific animal species and management of prey movements. DNA of animals can be extracted from sediments, and local presence of these species can be identified (Dussex et al., 2021; Haile et al., 2009). For example, parasite DNA from animal coprolites can chart the distribution of certain species and reflect human impact on them (Rawlence et al., 2014). DNA can be extracted from faunal remains, and this data can reflect the spatial distribution of animals based on geographic markers (Schlumbaum et al., 2008). Finally, past intense hunting pressure may have influenced population size and the distribution of targeted species. Studying the population dynamics of prey species through time using genetic studies can provide information about effective population sizes and whether one is dealing with a continuous ‘chrono-population' (individuals from older faunal assemblages are directly ancestral to the individuals from younger faunal assemblages) or whether faunal turnovers occurred, possibly as a result of hunting pressure. Such studies are in their infancy, but are promising.

Stable carbon, oxygen and strontium isotope data are used in studies of megafaunal mobility, their geographic range and anthropogenic and climatic factors influencing animals (Swift et al., 2019). Geographically and temporally different populations and subpopulations have distinct isotopic values (Hoppe, 2004; Price et al., 2017). Isotopes vary in terms of spatial resolution: hydrogen and oxygen are 'global-spatial' assays; carbon, nitrogen, sulphur and strontium are 'local-spatial'; and multiple isotopes can be combined to increase spatial resolution (Wassenaar, 2008).

Faunal remains studied via zooarchaeological methods can clarify hominin impact on animal populations within site-adjacent areas. Such research pays considerable attention to taphonomy because this directly influences skeletal part representation, age and sex profiles, the visibility of markers caused by human activity and 
other evidence used for inferences about past human behaviour (diet, subsistence practices, animal husbandry, food distribution, social and cultural variation in foodways) (Boethius, 2018; Landon, 2005). Preservation of bones and their information content varies between regions due to differences in soils and sedimentary geochemistry. Nevertheless, the general trend is characterised by the progressive loss of material through time (Surovell \& Pelton, 2016).

Finally, human-induced burning can be used as a tool for prey management as discussed above. Therefore, proxies related to anthropogenic burning (Table 1) can be used in research related to past relationships between humans and animals. However, these proxies should be used carefully; apart from the ubiquitous problem of differentiating natural from anthropogenic fires, humans used fires for varied purposes. Therefore, evidence for hunter-gatherer burning per se does not equal human impact on animal populations; more evidence is needed to warrant conclusions here.

Direct evidence of hominin impact on landscapes to impact animal presence and their abundance are fishing and hunting constructions, but their remains are rarely available for periods studied. Therefore, other proxies should be used to assess animal presence within specific locations: pollen indicators, AP/NAP, NPP, DNA and stable isotopes. However, these types of evidence should be linked with hominin presence and activity, because such proxies can reflect both the natural distribution of animals and anthropogenic impact on their presence. Faunal remains studied via zooarchaeological methods can clarify specific practices which were used by hominins to hunt and consume animals.

\section{Case Studies}

The following sections aim to illustrate the use of proxies in actual Middle Palaeolithic (Neanderthal) and Mesolithic archaeological contexts. These two types of context were chosen as an illustration because they were both formed under interglacial conditions with comparable climate (Svenning, 2002). The "The Visibility of Hunter-Gatherer Activity in Last Interglacial Records at Neumark-Nord" and "Impact of Mesolithic Hunter-Gatherers on Their Surroundings" sections focus on describing which proxies were extracted from both contexts and how they were interpreted for each of our categories of hunter-gatherer niche construction activities. We then assess whether the full range of proxies and best proxies are obtained and analysed in practice, and the extent to which this varies in older and younger contexts. We also discuss the strengths and weaknesses of the analysis of these proxies. A complete review of all relevant sites is beyond the scope of our paper, particularly for the Mesolithic; instead, we focus on case studies with large numbers of proxies that have a link to human activity. Finally, the current understanding of Neanderthal and Mesolithic impact on landscapes and common niche construction activities for both Neanderthals and Mesolithic humans are discussed. 


\section{The Visibility of Hunter-Gatherer Activity in Last Interglacial Records at Neumark-Nord}

The visibility of hunter-gatherer activities during the Eemian is heavily limited due to taphonomical factors affecting Last Interglacial records and as a result of research bias (Nielsen et al., 2015; Roebroeks \& Speleers, 2002). Neumark-Nord (Germany) is a rare example of a very rich and well-documented Last Interglacial location where different types of proxies (palaeoenvironmental and archaeological) were extracted from a landscape in which Neanderthals left a large amount of traces of their activities. At this location, the infill of two sedimentary basins has been submitted to a systematic investigation of Neanderthal activities and their environmental settings in an $~ 25$ ha large Last Interglacial lake landscape. The infill is dated by a series of independent methods, including Thermoluminescence studies of heated flint artefacts, Amino Acid Racemization studies of Bithynia opercula and palaeomagnetic analyses of the Neumark-Nord 2 sequence (see, e.g. Sier et al. (2011) and Gaudzinski-Windheuser et al. (2018) for a summary of the dating evidence). The unique preservation at Neumark enables researchers to trace environmental change and human subsistence over a period of approximately 11,000 years, with a spatial and temporal resolution virtually unparalleled in the Pleistocene record. The Last Interglacial record of Neumark consists of a large water basin (NN1), recorded in a series of long-term rescue archaeology interventions by Dietrich Mania and his team during exploitation of a large brown coal quarry, and an adjacent smaller pool (basin NN2), studied in great detail during programmed excavations. Lake basin NN1 was about 24 ha large, while basin NN2 represents a small and shallow pond, of about 1.6 ha in size. The fine-grained sedimentary infill of the two basins covers the complete Last Interglacial cycle. Multidisciplinary analyses at NN2 and correlations with the record from NN1 enabled accurate and high-resolution localisation of Neanderthal occupations and faunal assemblages in a palaeoecological framework. The Neumark archaeological record contains high-density evidence for flint knapping, animal exploitation and fire use (at NN2) as well as low-density single activity death or kill sites, mostly accumulated during the first 7,000 years of the Eemian. Comprehensive coverage of the Neumark palaeoecological and archaeological studies are assembled in Mania et al. (1990), Mania (2010), Meller (2010), Gaudzinski-Windheuser and Roebroeks (2014), Gaudzinski-Windheuser et al. (2018) and Kindler et al. (2020) (for various detailed studies of a wide range of proxies from Neumark-Nord, see Mania, 2010; Meller, 2010; Bakels, 2012, 2014; Britton et al., 2012, 2019; García-Moreno et al., 2016; Milano et al., 2020).

Based on analysis of lithic assemblage and faunal remains, the NN2 site was characterised as a location where hundreds of medium-sized and large herbivores were processed during a well-constrained period of the Eemian Interglacial, with hominins revisiting the area over a period of minimally 2,000 years (Pop et al., 2016) and with a striking absence of traces of carnivore modification of the abundant faunal remains (Gaudzinski-Windheuser et al., 2018). The frequency and the duration of the occupation events is still an open question (Pop, 2014). Samples for analysis of pollen, charcoal and animal remains were taken every $5 \mathrm{~cm}$ from the lithostratigraphic units of Hauptprofil 7 (Main profile 7) in a deeper part of the basin 
NN2 (Kuijper, 2014; Pop \& Bakels, 2015). The rich archaeological find levels at the margins of the basin, located $\sim 20 \mathrm{~m}$ from this profile, were easily positioned within the lithostratigraphy of Hauptprofil 7 thanks to the continuous exposures between the two locations (ibid.). Episodes with an open park-like forested area around the site were identified for NN2 during the period of hominin presence. It was suggested that such a type of environment could have been created via a combination of different types of disturbances: herbivores, aridity and Neanderthal fire practices (ibid.). This suggestion was based on pollen data (high percentages of herb pollen), charred plant macrofossils, macroscopic charcoal, thermally altered lithics (charcoal particles correlate with altered lithics) (Fig. 1) and faunal remains (most remains from

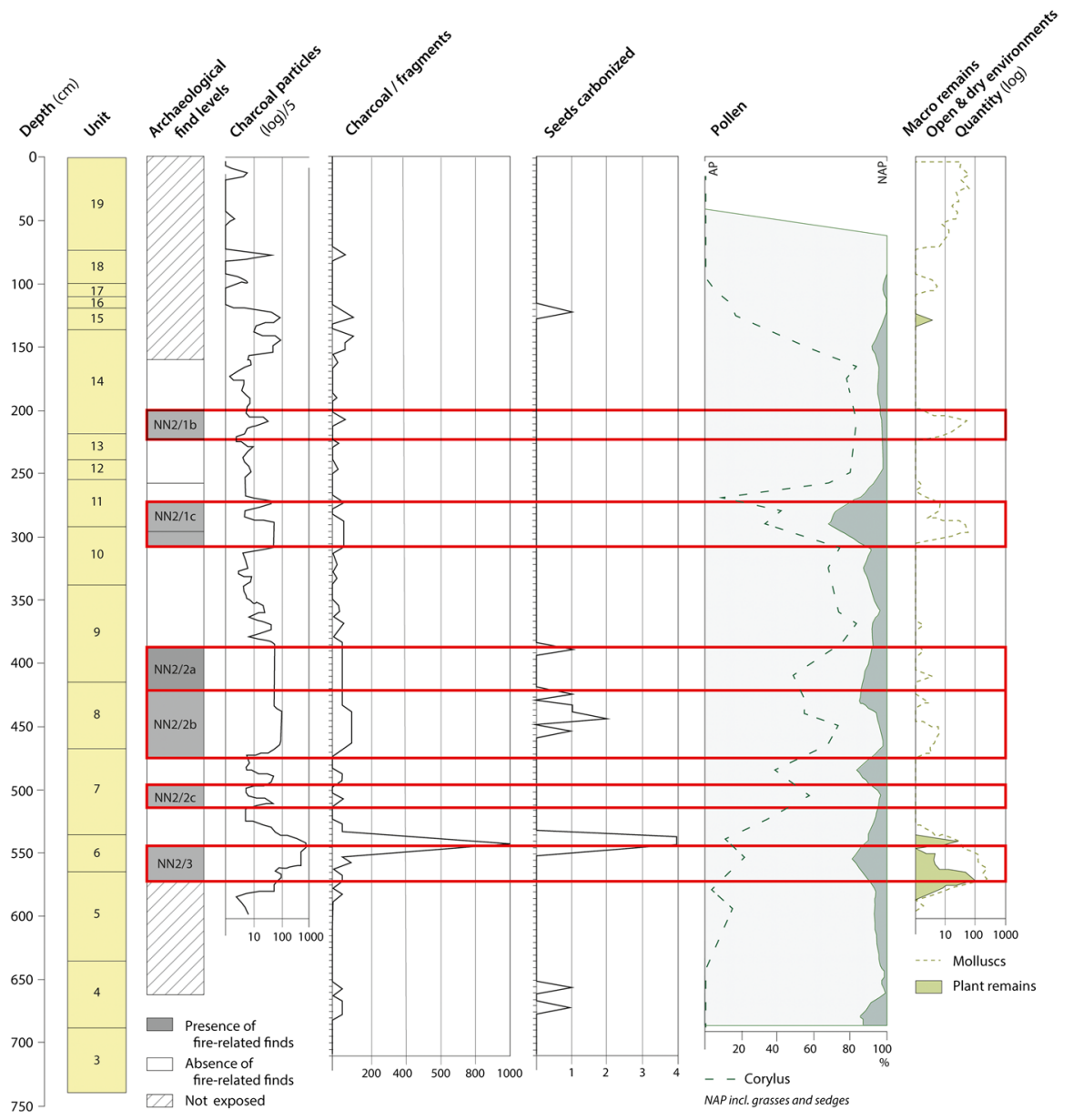

Fig. 1 Neumark-Nord 2 (Germany) HP 7 sequence, with lithological units and the archaeological find levels (Sier et al., 2011), the stratigraphical distribution of charcoal particles, carbonised seeds (Kuijper, 2014), arboreal (AP) and non-arboreal pollen (NAP) and data regarding vegetation openness (Pop \& Bakels, 2015); correlation of archaeological layers containing fire-related findings with vegetation openness episodes shown in red 
the archaeological level NN2/2b belong to bovid and horse; wild ass, small cervid and roe deer may also be present, and several fragments attest to giant deer, wild boar, rhino and elephant) (Kindler et al., 2014). Kuijper's (2014) detailed study of the charcoal particles in the infill of the NN2 basin showed their presence all through the interglacial sequence, but with a very noticeable peak at the beginning of Neanderthal presence at the site, with ten times the amount of charcoal of any other peak in the sequence (Fig. 1, archaeological level NN2/3). Importantly, this charcoal peak and the beginning of a strong Neanderthal presence also coincide with significant changes in the vegetation: following the earlier (pre-Neanderthal occupation) expansion of taller deciduous forest, the landscape opens up, with a strong rise of upland herbs in the pollen curve and the beginning of a long Corylus avellana (hazel) period (Bakels, 2014; Gaudzinski-Windheuser \& Roebroeks, 2014; Pop et al., 2016; Roebroeks \& Bakels, 2015) (Fig. 1). Local-scale transformations of the natural landscape took place around the site when Neanderthals arrived, but it is not possible to establish if this correlation indicates causation (see below). The NN2 evidence however could reflect Neanderthal actions, specifically burning, to open up the area and attract game and increase plant food resources (Pop \& Bakels, 2015; Roebroeks \& Bakels, 2015). The hypothesis about creation of open habitats by Neanderthals was supported via comparative study of the Neumark-Nord basins with the records from comparable Last Interglacial basins in the area: Gröbern, Grabschütz and Rabutz (Roebroeks et al., in press). NN2 and these sites have common characteristics: similar soil conditions, basin forms, climatic conditions and presence of large mammals which preferred both closed forest conditions and open areas. However, data from the Neumark-Nord area demonstrates unusual vegetation openness around basins, whereas there was relatively closed forest vegetation around other sites. Continuous vegetation openness around Neumark-Nord basins matches with 2,000 years of Neanderthal presence, and, therefore, this vegetation change cannot be explained only by climatic shifts or megafauna impact.

Close-range hunting of large herbivores by occupants of this larger lake area was identified based on hunting lesions on fallow deer bones (Gaudzinski-Windheuser et al., 2018) at NN1. Neanderthals also played an almost exclusive role in bone accumulation at NN2 where large amounts of bone fragments with cutmarks accumulated (archaeological level NN2/2b, Fig. 1) (Gaudzinski-Windheuser \& Roebroeks, 2014; Pop et al., 2018). Molluscs (discovered in units 18-16, 6, 4), fish (discovered in units 18-top 15, 6, 5, 4) and bird remains (egg fragments were discovered in units 19-17, 11, 6 and 5) are also abundantly present in the infill. The diet of the occupants may have included Prunus spinosa (blackthorn), Quercus sp. (acorn), and hazelnut, as their charred macroremains were discovered during excavations of archaeological level NN2/2 (Kuijper, 2014). Charred hazelnuts are also known from the neighbouring Last Interglacial archaeological site Rabutz (Toepfer, 1958). Based on analysis of coarse gravel- and cobble-sized stones transported by Neanderthals to the NN2 location, mainly quartzite and sandstone, some of these manuports were used for percussive tasks (lithic production and potentially bone processing) without contact with soft materials (e.g. nut processing) (Pop et al., 2018).

Thus, the subsistence activities of hunter-gatherers at Neumark-Nord were clarified based on a multi-proxy approach, applied to a series of sediments preserved 
in rather unique basin structures over large areas beneath a cover of Weichselian loess, with a spatial and temporal resolution unparalleled in the Pleistocene record. These taphonomically unique sediment traps allowed a detailed study of Neanderthal subsistence activities, identified via faunal remains with preserved anthropogenic traces, lithic assemblages and plant macrofossils. Local-scale transformations of the natural surroundings of the small lake of NN2 occurred when Neanderthals arrived, a correlation for which there are two plausible explanations: either Neanderthals started to frequent the location because the landscape had been opened up by natural fires as testified by the large charcoal peak in the lower part of the sequence (see Fig. 1) or their arrival opened up the landscape, e.g. by their use of fire (Pop \& Bakels, 2015; Roebroeks \& Bakels, 2015). Sedimentation of the infill of the central part of the NN2 basin was rapid and nearly continuous, with estimated sedimentation rates for the archaeology-yielding deposits varying from 0.11 to $0.24 \mathrm{~cm} /$ year (Sier et al., 2011), yielding a high-resolution NN2 sequence. That is why this case study provides an example of the dynamic character of environments and how they can be transformed via the impact of several agents (hominins, herbivores and climate), with likely Neanderthal impact on surroundings. Currently, despite the large amount of high-resolution environmental data, it is not possible to identify which agent caused which types of changes at this particular location. Situating the local Neumark-Nord evidence within the wider regional record, by comparing it with similar Last Interglacial basins without an archaeological record, may enable better identification of the specific roles of the various actors, including large mammals and hominins (Roebroeks et al., in press).

\section{Impact of Mesolithic Hunter-Gatherers on Their Surroundings}

It is widely accepted that Mesolithic populations impacted their surroundings via burning in different parts of Europe (Davies et al., 2005; Mason, 2000). Anthropogenic burning has been identified around such sites as Meerstad (the Netherlands) (Woldring et al., 2012), the Lahn valley complex (Germany) (Bos \& Urz, 2003), Dudka Island (Poland) (Gumiński \& Michniewicz, 2003), Star Carr (England) (Mellars \& Dark, 1998; Milner et al., 2018), Dumpokjauratj and Ipmatisjauratj (Sweden) (Hörnberg et al., 2006), Vingen sites (Djupedalen, Vingeneset and Vingen terrace in Norway) (Hjelle \& Lødøen, 2017) and the rock art park of Campo Lameiro (Spain) (Kaal et al., 2013). Table 4 shows that vegetation burning was mainly identified based on increased charcoal concentrations and the presence of pollen produced by species indicative of open/disturbed areas. These types of evidence were associated with archaeological records of human activity within and around sites, and therefore these burning events were interpreted as human-induced fire episodes (Bos \& Urz, 2003; Gumiński \& Michniewicz, 2003; Hjelle \& Lødøen, 2017; Hörnberg et al., 2006; Kaal et al., 2013; Mellars \& Dark, 1998; Milner et al., 2018; Woldring et al., 2012). As we can see, one type of evidence (pollen spectra) dominates in such studies; in fact, the data from the Lahn valley is outstanding because more types of proxies were related to human-induced burning there. Therefore, this case study is 


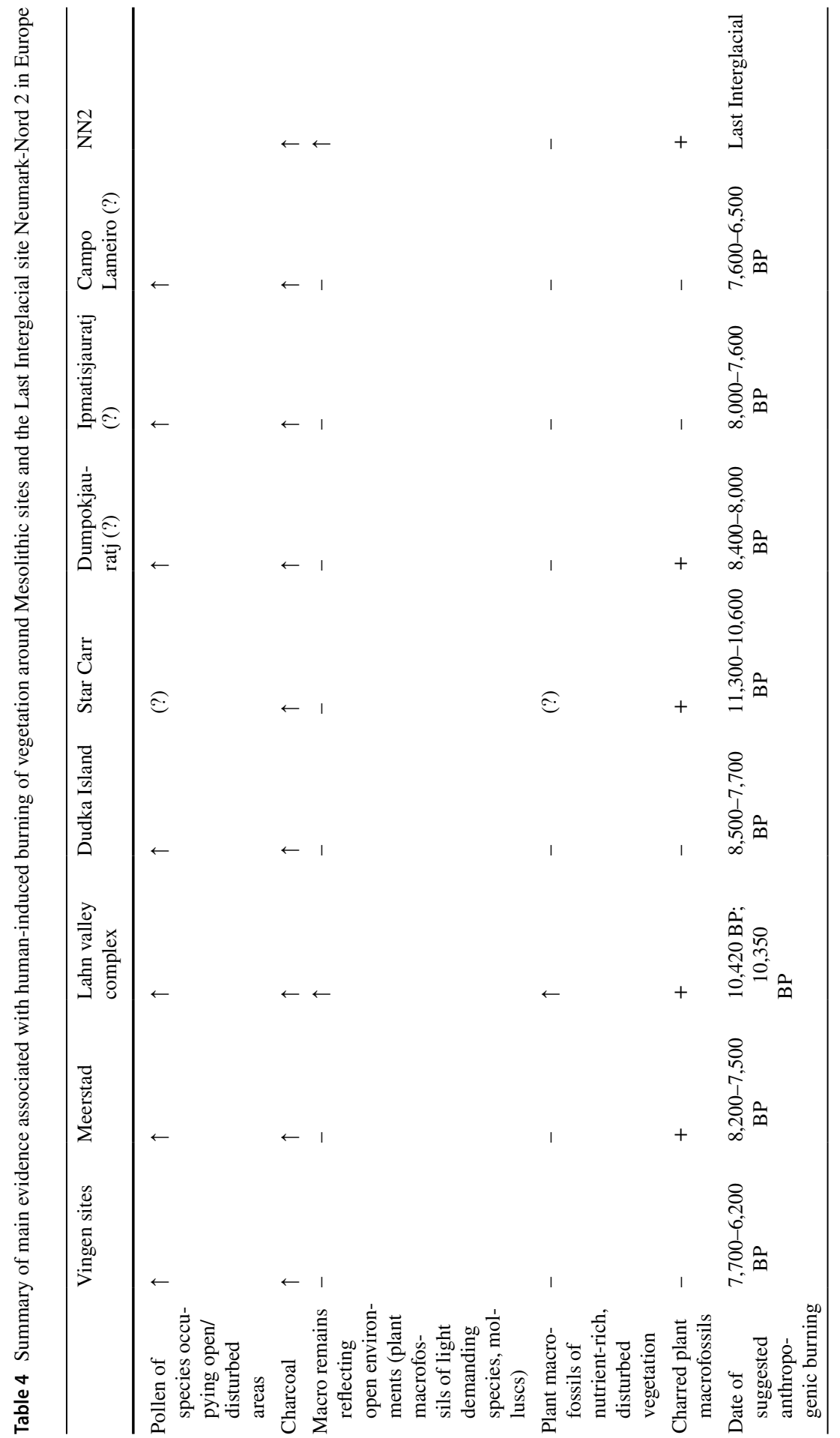




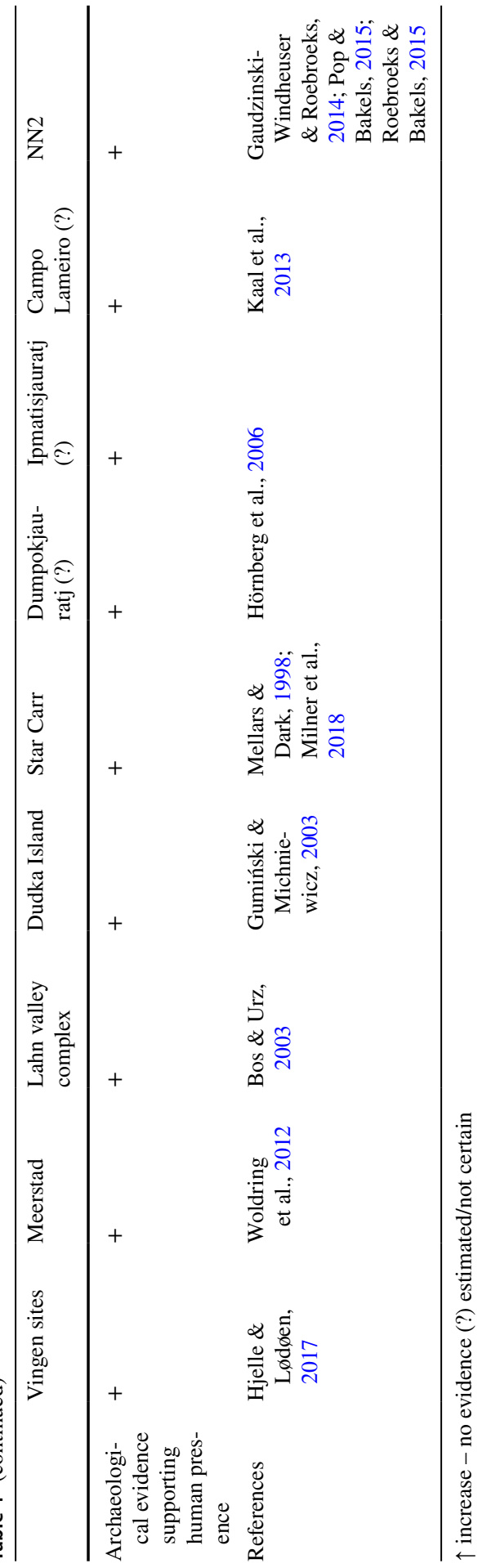


discussed in more detail below in accordance with the article published by Bos and Urz (2003).

Archaeological sites from the Lahn valley area in Germany were investigated at a high chronological resolution. Niederweimar 6 (NW6) and Niederweimar 8 (NW8) are two early Mesolithic archaeological sites discovered in 1994 during gravel mining. They are both located on river terraces along Holocene residual channels. Lithics and carbonised animal teeth were found within NW8, and a Mesolithic campsite was identified within NW6 where concentrations of artefacts and a fireplace were found. Geomorphological and palaeobotanical research was conducted in conjunction with pollen analysis and radiocarbon dating to reconstruct vegetation transformations in this area. Plant microfossils were collected from different well defined and dated residual channel fills, and pollen data was collected from three sediment profiles along a transect at different distances $(75-200 \mathrm{~m})$ from the archaeological sites. Pollen samples were taken from palaeochannel fills of the river Lahn. Charcoal concentrations and NAP totals were calculated. Nineteen samples were AMS dated to obtain a chronostratigraphical framework which covers the period between 11,640 BP and 8,830 BP. Mesolithic settlement existed in this area between around $10,940 \mathrm{BP}$ and 10,360 BP.

Several proxies were combined to make hunter-gatherer landscape changes visible in the records. Correlation between different types of evidence was conducted via absolute dating, fluvial geomorphology and comparison of diagrams. As a result, large amounts of charcoal, high percentages of light demanding taxa and plants indicating a nitrogen- and nutrient-rich environment (i.e. disturbed surroundings and input of organic material) (Fig. 2), along with the presence of Mesolithic occupation traces in the area, were interpreted as evidence of human impact on landscapes via clearance and burning. In particular, high percentages of charcoal and macrofossils reflecting nutrient-rich and disturbed places, and the reduction of woody plant macrofossils around 10,420 BP (Fig. 2), were interpreted as indicating clearance and deliberate burning of the pine, birch and hazel-rich woodlands leading to the expansion of more open vegetation. The second phase of human impact in the oak, elm and hazel-rich woodlands took place around 10,350 $\mathrm{BP}$, based on the identification of the second-highest charcoal peak along with a relatively high percentage of macrofossils from nutrient-rich and disturbed places. In addition, several periods of openness in hazel woodlands were discovered based on the pollen spectrum (Fig. 2).

The presence of bones (some with cutmarks) of wild animals reflect the importance of hunting for occupants from the Lahn area. Hence, game attraction may have been one of the main reasons for vegetation burning. Ease of human movement could also be mentioned as a possible reason for fire practices. The discovery of hazelnut fragments (both charred and uncharred) in archaeological layers led the authors to the conclusion that promotion of the growth of edible plants such as hazel was one more reason for burning vegetation (Bos \& Urz, 2003). However, it is important to highlight that coppicing and pruning were important ways to promote edible plants, and these techniques were quicker ways to increase plant growth in comparison with vegetation burning (Bishop et al., 2015). Additionally, naturally good growing conditions could promote hazelnut growth (Groß et al., 2019). 

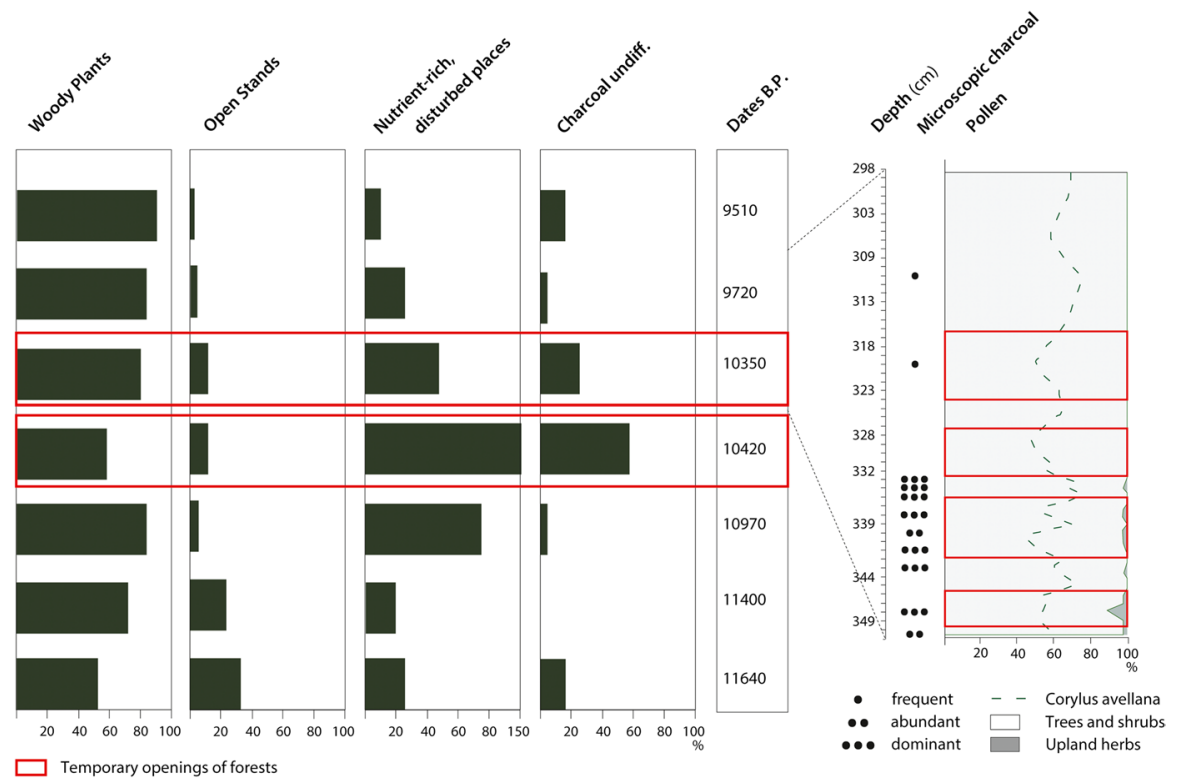

Fig. 2 Pollen analysis (pollen percentage of trees, shrubs, upland herbs and Corylus avellana) from Weimar-Niederweimar II. 2 profile and macrofossil evidence (percentage of wood, charcoal and remains from plants occupying open, disturbed and nutrient-rich areas) from different palaeochannel fills at WeimarNiederweimar (Germany). The sequence shown here is dated to the Younger Dryas (11,640 BP, gravel layer), Preboreal (11,400-10,970 BP, gravel layer) and Boreal periods (10,420-9,510 BP, sand/gyttja and gyttja layers); phases of Early Mesolithic anthropogenic impact within the Lahn valley area are shown in red (after Bos \& Urz, 2003)

Regarding plant manipulation, macrofossils of plants have been found in Mesolithic layers within sites in the Netherlands and Great Britain (e.g. Ficaria verna, lesser celandine), Denmark (e.g. Allium cf. ursinum, ramsons and Conopodium majus, pignut), and Poland (e.g. Sagittaria cf. sagittifolia, arrowhead) (Klooss et al., 2016; Kubiak-Martens, 2015). Due to the fact that tubers and roots of these plants were discovered as charred remains, researchers have concluded that these plants were part of the Mesolithic diet. Roots and tubers could have been abundant, starch-rich and easily available foods in temperate Europe. The starch content of these plants would have made a significant dietary contribution and made their enhancement worthwhile. Macrofossils of hazel and nut processing equipment were discovered in Mesolithic layers within different sites (e.g. Divišová \& Š́da, 2015; Groß et al., 2019; Holst, 2010; Regnell, 2012), and, therefore, this plant is currently considered one of the most important vegetable components of the Mesolithic diet. However, intensive exploitation of hazelnuts may be a response to good growing conditions rather than a result of human intervention (Groß et al., 2019). Not only nuts but also other parts of plants have been found in Mesolithic assemblages which indicate that variable parts of plants were available for people, though specific types of plant manipulation are difficult to identify based on such evidence. Additionally, tools potentially related to Mesolithic plant manipulation were discovered within different European sites: wooden hoes and mattocks, antler artefacts interpreted as 
tools for a range of purposes including digging, and blades and microblades with traces of plant processing (Zvelebil, 1994). However, these tools could have been used for varied purposes, and unambiguous identification of their actual use is difficult to achieve. Mesolithic populations may have carried out small-scale plant manipulation for purposes other than obtaining food. In particular, the number of wooden artefacts discovered increased in the Mesolithic in comparison with preceding periods. Coppicing and forest clearing have been mentioned as possible methods to obtain wood materials of the properties required to produce tools or construct structures for variable purposes (e.g. McQuade \& O'Donnell, 2007; Warren et al., 2014; Bamforth et al., 2018). Overall, it is difficult to distinguish unmanaged wood from coppicing remains left by humans (Out et al., 2013).

Animal presence within specific locations is often difficult to link directly with hunter-gatherer activity without evidence of special constructions (e.g. fences or traps) for the management of animal movements and distribution. Constructions for management of aquatic resources were identified within Mesolithic sites such as North Wall Quay in Ireland (McQuade \& O'Donnell, 2007), and Zamostje 2 in Russia (Lozovski \& Lozovskaya, 2016). The importance of aquatic resources for some Mesolithic groups was also supported via a combination of different proxies: several types of evidence were obtained as the result of zooarchaeological analysis interpreted in conjunction with ethnographic analogues (evidence of fish extraction in large quantities, year-round seasonality indicators, determination of species, etc.), archaeological (presence of mass catching equipment and a fish fermentation facility) and isotope studies (high dietary intake of aquatic resources by humans) in southern Scandinavia (Boethius, 2018). Terrestrial structures have not been discovered in Europe yet. An example of a study in which a link has been made to huntergatherer activity for terrestrial animals without the presence of special constructions is the North Gill site in England (Innes \& Blackford, 2003). There are several exposed peat sections at the site, the base of which is rich in charcoal and contains evidence of fire disturbance. One of the previously defined basal disturbance phases at the site was studied via analysis of fungal spores in conjunction with alreadypublished charcoal and pollen counts. Samples were extracted from the basal disturbance phase at core North Gill 5B. Fungal spores were counted from the same slides as for the pollen and charcoal data derived from the basal disturbance phase at core North Gill 5B. Post-disturbance phases after burning were reflected in pollen (abundance of Melampyrum as the initial post-fire flora), charcoal concentrations and fungi (Neurospora and Gelasinospora) counts (Fig. 3). An increased amount of dung fungus (e.g. Sporormiella) and pollen of Succisa and Potentilla-type during the post-disturbance transitional phases may reflect the presence of herbivores and intensive grazing. This data supports the view that recently burned areas were attractive for game. Two factors were considered causes of burning events leading to an increase in grazing activities: anthropogenic burning and climatic impact (ibid.; Innes \& Blackford, 2017).

Therefore, data from several European archaeological sites has been interpreted by researchers as evidence of vegetation burning organised by hunter-gatherers during the Mesolithic. Such evidence mainly includes increases in charcoal concentrations and pollen of species occupying open/disturbed areas while Mesolithic 


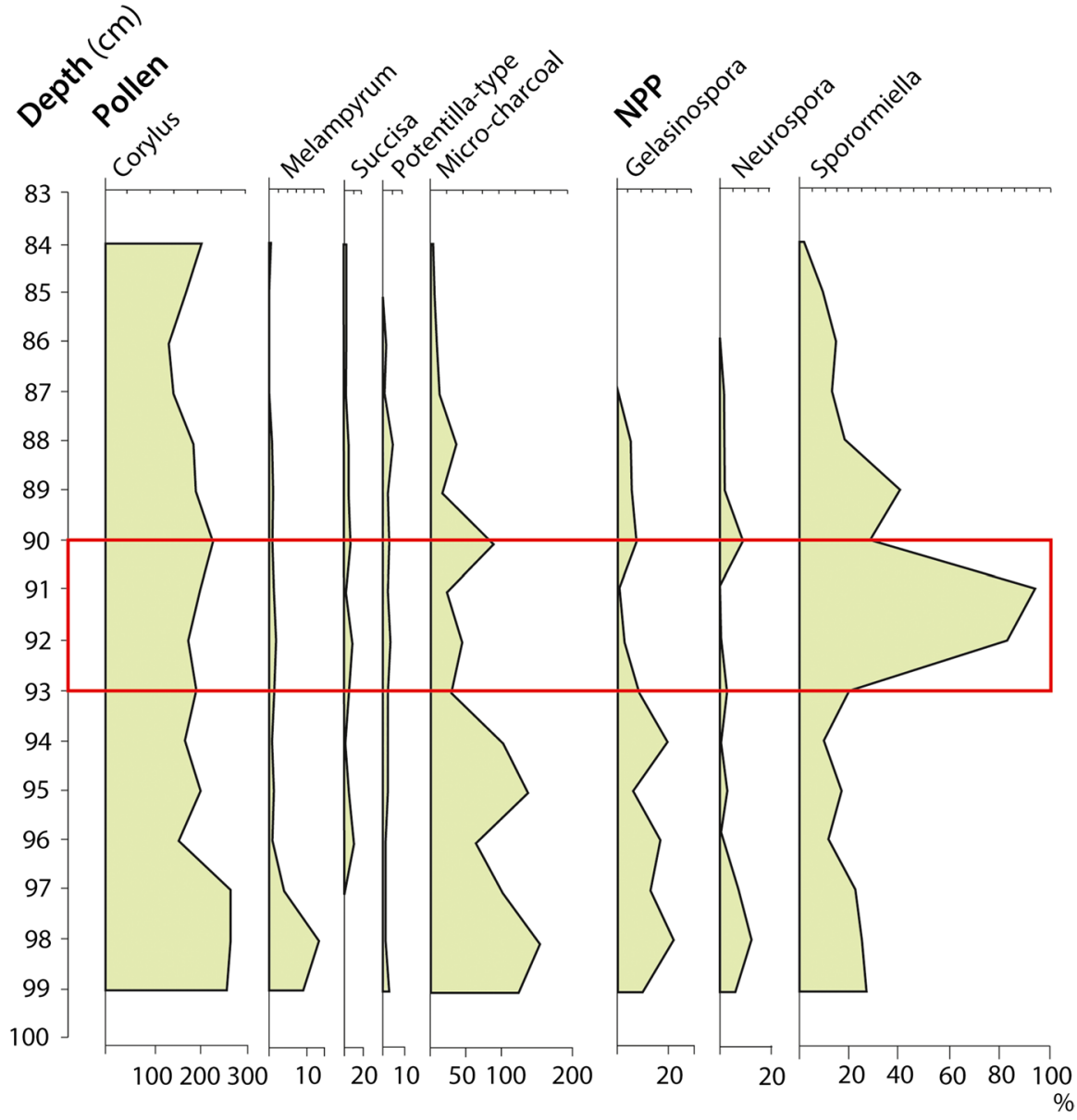

Fig. 3 Pollen analysis (pollen percentage of Corylus, Melampyrum, Succisa, Potentilla-type and microcharcoal) and NPP evidence (percentage of Gelasinospora, Neurospora, Sporormiella) from a profile at North Gill 5B (North York Moors within England and Wales). This evidence reflects post-disturbance phases after burning and intensive grazing during the Late Mesolithic at North Gill. The profile consists of amorphous peat resting on sand at $100 \mathrm{~cm}$. The inferred age of the basal peat lies within the Late Mesolithic based on dates available for a section a few tens of metres away from North Gill 5 (5,270 BP) and higher section of this site $(4,540 \mathrm{BP}$ at $73 \mathrm{~cm}$ ) (after Innes \& Blackford, 2003). Red shows the phase with the highest herbivore concentrations; this follows a phase with intensive burning

people were present in the areas. Anthropogenic burning was mostly local and during favourable conditions for the spread of fire could impact surroundings more dramatically. The high importance of plants in the Mesolithic diet was mainly identified based on the presence of charred and not charred plant remains within cultural layers. Specific types of plant manipulation could be suggested based on tools discovered in different archaeological sites in Europe. Mesolithic people also used aquatic and terrestrial animal resources, but the direct evidence (e.g. traps, fences) of huntergatherer impact on animal presence and their abundance in specific locations is only 
available for the former. NPP and pollen spectra reflected high grazing activity, but a strong link between human activity and high concentrations of herbivores around a specific site has not been established.

\section{Discussion}

Currently, identifying what niche construction activities Last Interglacial and Early-Middle Holocene hunter-gatherer populations had in common is complicated due to the scarcity of well-documented sites, especially for the Last Interglacial. A further issue lies in weaknesses in the argument connecting proxies with landscape management activities: anthropogenic burning provides a good example.

Anthropogenic burning of the immediate surroundings of Eemian and Mesolithic camp sites was identified in a series of inferential steps. Firstly, proxies were observed reflecting changes in the vegetation cover. Secondly, further interpretation emphasises that these vegetation transformations were caused by burning. A next step in the interpretation linked these fire events to hominin activity, and to hominin firing of the landscape. Finally, this burning was interpreted in terms of intentional landscape transformation by hunter-gatherers.

The first and the second steps are reproducible and relatively easy to support with empirical data, built on various proxies ("Proxies for Identification of Modification of Vegetation Communities Via Burning" section) and their analyses. The transition from the second interpretation step towards linking the specific fire with human activity is much more difficult, but can ideally be inferred on the basis of a high-resolution archaeological context and/or setting of the proxies. However, due to the time-averaged nature of the archaeological records even for high-resolution data associated with evidence of hominin presence, it is not possible to definitively establish if this correlation reflects anthropogenic landscape changes or hominins occupied the area right after or during landscape changes caused by natural factors. The last step, leading to the conclusion about intentional hunter-gatherer landscape management, is the most difficult, because this step needs to be supported by robust evidence regarding the intentions of past populations. In the absence of such robust data, the Eemian and Mesolithic case studies lack a solid link between data and conclusions about the intentional nature of anthropogenic burning, be it Last Interglacial or Early-Middle Holocene in age.

What one can minimally observe is that a similar set of proxies was available for both the Last Interglacial and the Holocene case studies. The main evidence used to assess hunter-gatherer vegetation burning in these periods are increases in charcoal concentrations, as well as pollen and macrofossils indicative of open/disturbed areas when hominins were present (Table 4). Both Neanderthals and Mesolithic humans were considered by researchers as possible agents of landscape transformations, and currently local-scale vegetation burning could be considered a common niche construction activity for both Neanderthals and Mesolithic populations.

Regarding other niche construction activities, we suggest that plant manipulation and control of animal presence were common activities for Neanderthals and Mesolithic populations, because charred plant microfossils, stone tools with evidence of 
plant manipulation (e.g. from the Middle Paleolithic site of Payre in France; Hardy \& Moncel, 2011; Osipowicz, 2019), plant microremains from dental calculus (e.g. Cristiani et al., 2016; Henry et al., 2011, 2014) and large numbers of animal bones accumulated through butchering activities were identified within both Middle Palaeolithic and Mesolithic sites. Additionally, management of aquatic resources by Mesolithic populations has been demonstrated based on several types of evidence including fish traps and faunal remains. Manipulation of wood raw materials has also been suggested in the Mesolithic, but is difficult to demonstrate.

Given the available evidence, one cannot postulate significant differences between the categories of niche construction practices conducted by Neanderthals and Mesolithic humans, and likewise there exists no unambiguous proof that the observed fire events were the intended outcomes of vegetation burning by populations during both periods. While this suggests that both populations influenced their landscapes on a local scale at least, it is not clear whether there is any difference on larger spatial scales. Currently, the main way of assessing possible larger-scale differences lies in estimates of population sizes, but these are notoriously difficult to establish. Additional studies are necessary to assess whether repetitive landscape transformation activities on a local scale could have caused shifts in vegetation composition on regional - and possibly (sub-)continental - levels during the Eemian and the Holocene, and which population densities of hunter-gatherers are needed for such changes to become visible on such scales.

To fill existing gaps in research about dynamic interglacial environments and the role of Homo with different demographic settings in landscape changes, further research endeavours could include not only standard procedures such as palynological analysis and estimation of charcoal concentrations, but also extraction of less common proxies (e.g. DNA from sediments, phytoliths, parenchyma and other evidence mentioned in the "Types of Evidence Related to Past Hunter-Gatherer Niche Construction Activities" section). However, the possibilities for using a combination of proxies for such studies depend on taphonomic processes and on data availability determined by previous research. Such a multi-proxy approach could potentially help to overcome the specific resolution limitations of each method, to make the hunter-gatherer signal more visible, and to separate human-induced changes from transformations caused by other processes (climatic fluctuations, megafauna activities, etc.). Modelling efforts might be helpful in making the transition from local to regional to (sub-)continental research. Depending on the modelling type, local-scale evidence could form one of the inputs into a model, or could be used later at a validation stage.

\section{Conclusion}

Three categories of hunter-gatherer niche construction activities were described in accordance with ethnographic observations: (1) modification of vegetation communities via burning; (2) small-scale plant manipulation; (3) landscape modification to impact the presence of large animals and their abundance in specific locations. Every niche construction practice can potentially be identified via several types of 
evidence. However, the actual visibility of these activities depends on several factors. These include the impact of taphonomic processes on the extraction and analysis of evidence (i.e. over-representation of some proxies or indicators and underrepresentation or complete absence of others); spatial scale (i.e. reflection by some proxies of past processes on local and regional scales, others on (sub-)continental scales); temporal representation (i.e. the tendency for younger things to be better represented than younger things in the archaeological record); and research strategy during field studies which defines further analysis.

Case studies showed that similar sets of proxies (mainly charcoal concentrations, pollen and macrofossils of species reflecting open and disturbed areas) exist for possible Neanderthal and Mesolithic firing of vegetation. Anthropogenic (intentional) changes of vegetation during the Mesolithic are commonly accepted on the basis of these proxies. The Neumark-Nord case study illustrated that data exists for the Last Interglacial that in terms of their information quality match the best Mesolithic cases known. Hence, Last Interglacial Neanderthals' impact on their surroundings was occasionally very much comparable to that of Mesolithic hunter-gatherers. However, the absence of unambiguous methods to clearly distinguish between hominin, climatic and megafaunal local impact on vegetation during both periods forces us to be careful in interpreting these firing activities. In general, many studies have inferred a relationship between observed proxies for vegetation transformation via burning and hominin activities identified based on the archaeological context and/ or setting of the proxies. These correlations were then translated into conclusions about hunter-gatherer intentional landscape transformations via burning. However, the intentional nature of anthropogenic landscape changes is difficult to verify, even in high-resolution cases. The currently available data and amount of research could allow researchers to consider local-scale vegetation burning as a common niche construction activity for both Neanderthals and Mesolithic populations. Other suggestive niche construction activities organised by foragers during both time periods are plant manipulation and impact on animal presence and their abundance.

In short, given the significance of the Eemian interglacial as an 'analogue for present-natural vegetation' for the Holocene, clarifying the role of fire using Neanderthals in the past landscapes under scrutiny is important. To identify the extent of past hunter-gatherer impact on surroundings, more precise estimations of population sizes are necessary, hence the need for further research. In addition to longestablished research methods (e.g. pollen analysis and the study of charcoal particles), future research endeavours should try to make use of less common techniques such as sediment DNA, phytoliths and starch grains. Studies of past hunter-gatherer landscape changes should mainly rely on evidence with a local spatial resolution (Tables 1, 2, and 3), reflecting the scale at which hunter-gatherer activities had an impact. The transition from local to regional to (sub-)continental research can be made via modelling which can include information obtained from proxies as an input to models or as the way to test modelling results. Additional studies are necessary to assess whether repeated activities by hunter-gatherers causing landscape transformation on a local scale led to shifts in vegetation composition on regional and (sub-)continental scales, or not, and which population density of foragers could cause such significant changes. 
Acknowledgements The research is financed through the European Union's Horizon 2020 research and innovation programme within the TERRANOVA project, No 813904, and supported by the Liveable Planet programme of Leiden University. The paper reflects the views only of the authors, and the European Union cannot be held responsible for any use which may be made of the information contained therein. Jens-Christian Svenning considers this work a contribution to his VILLUM Investigator project "Biodiversity Dynamics in a Changing World" funded by VILLUM FONDEN (grant 16549). We would like to thank Prof. Jan Kolen and Prof. Corrie Bakels (Leiden University, Leiden, the Netherlands) for inspiring discussions.

Open Access This article is licensed under a Creative Commons Attribution 4.0 International License, which permits use, sharing, adaptation, distribution and reproduction in any medium or format, as long as you give appropriate credit to the original author(s) and the source, provide a link to the Creative Commons licence, and indicate if changes were made. The images or other third party material in this article are included in the article's Creative Commons licence, unless indicated otherwise in a credit line to the material. If material is not included in the article's Creative Commons licence and your intended use is not permitted by statutory regulation or exceeds the permitted use, you will need to obtain permission directly from the copyright holder. To view a copy of this licence, visit http://creativecommons.org/licen ses/by/4.0/.

\section{References}

al Khasawneh, S., Murray, A., Thomsen, K., AbuAzizeh, W., \& Tarawneh, M. (2019). Dating a near eastern desert hunting trap (kite) using rock surface luminescence dating. Archaeological and Anthropological Sciences, 11, 2109-2119. https://doi.org/10.1007/s12520-018-0661-3.

Albert, R. M., \& Cabanes, D. (2007). Fire in prehistory: An experimental approach to combustion processes and phytolith remains. Israel Journal of Earth Sciences, 56, 175-189. https://doi.org/10. 1560/IJES.56.2-4.175.

Allred, B. W., Fuhlendorf, S. D., Engle, D. M., \& Elmore, R. D. (2011). Ungulate preference for burned patches reveals strength of fire-grazing interaction. Ecology and Evolution. https://doi.org/10. $1002 /$ ece 3.12.

Alperson-Afil, N. (2017). Spatial analysis of fire archaeological approach to recognizing early fire. Current Anthropology, 58(16), 258-266. https://doi.org/10.1086/692721.

Andermann, T., Faurby, S., Turvey, S. T., Antonelli, A., \& Silvestro, D. (2020). The past and future human impact on mammalian diversity. Science Advances, 6. https://doi.org/10.1126/sciadv.abb23 13.

Anderson, M. K. (2005). Tending the wild. Native American knowledge and the management of California's natural resources. University of California Press.

Anderson, D. G., Harrault, L., Milek, K. B., Forbes, B. C., \& Kuoppamaa, M. (2019). Animal domestication in the high Arctic: Hunting and holding reindeer on the TAmal peninsula, northwest Siberia. Journal of Anthropological Archaeology, 55. https://doi.org/10.1016/j.jaa.2019.101079.

Anthropocene Working Group. (2019). Newsletter of the Anthropocene Working Group, 9.

Bailey, G., Andersen, S. H., \& Maarleveld, T. J. (2020). Denmark: mesolithic coastal landscapes submerged. In G. Bailey, N. Galanidou, H. Peeters, H. Jöns, \& M. Mennenga (Eds.), The Archaeology of Europe's Drowned Landscapes (pp. 39-76). Springer International Publishing.

Bakels, C. (2012). Non-pollen palynomorphs from the Eemian pool Neumark-Nord 2: Determining water quality and the source of high pollen-percentages of herbaceous taxa. Review of Palaeobotany and Palynology, 186, 58-61. https://doi.org/10.1016/j.revpalbo.2012.06.003.

Bakels, C. (2014). A reconstruction of the vegetation in and around the Neumark-Nord 2 basin, based on a pollen diagram from the key section HP7 supplemented by section HP10. In S. GaudzinskiWindheuser \& W. Roebroeks (Eds.), Multidisciplinary studies of the Middle Palaeolithic record from Neumark-Nord (Germany) (pp. 97-108). Landesmuseum für Vorgeschichte.

Bakker, E. S., Gill, J. L., Johnson, C. N., Vera, F. W. M., Sandom, C. J., Asner, G. P., \& Svenning, J.-C. (2016). Combining paleo-data and modern exclosure experiments to assess the impact of megafauna extinctions on woody vegetation. PNAS, 113(4), 847-855. www.pnas.org/cgi/doi/10.1073/ pnas. 1502545112 . 
Bamforth, M., Taylor, M., Taylor, B., Robson, H. K., Radini, A., \& Milner, N. (2018). Wooden Structures. In N. Milner, C. Conneller, \& B. Taylor (Eds.), Star Carr, A Persistent Place in a Changing World (Vol. 1, pp. 69-121). White Rose University Press.

Bar-Yosef, O. (2004). Eat what is there: hunting and gathering in the world of Neanderthals and their neighbours. International Journal of Osteoarchaeology, 14, 333-342. https://doi.org/10.1002/oa. 765.

Behre, K.-E. (1981). The interpretation of anthropogenic indicators in pollen diagrams. Pollen et Spores, 23(2), 225-245.

Berti, E., \& Svenning, J. C. (2020). Megafauna extinctions have reduced biotic connectivity worldwide. Global Ecology and Biogeography, 29(12), 2131-2142. https://doi.org/10.1111/geb.13182.

Bettinger, R. L. (2001). Holocene hunter-gatherers. In G. M. Feinman (Ed.), Archaeology at the Millennium (pp. 137-195). Springer.

Bird, R. B., Bird, D. W., Codding, B. F., Parker, C. H., \& Jones, J. H. (2008). The "fire stick farming" hypothesis: Australian Aboriginal foraging strategies, biodiversity, and anthropogenic fire mosaics. PNAS, 105(39), 14796-14801.www.pnas.org/cgi/doi/10.1073/pnas.0804757105.

Birks, H. H. (2001). Plant macrofossils. Introduction. In J. P. Smol, H. J. B. Birks, \& W. M. Last (Eds.), Tracking Environmental Change Using Lake Sediments (pp. 49-74). Kluwer.

Birks, H. J., \& Birks, H. H. (2016). How have studies of ancient DNA from sediments contributed to the reconstruction of Quaternary floras? New Phytologist, 209(2), 499-506.

Bishop, R. R., Church, M. J., \& Rowley-Conwy, P. A. (2015). Firewood, food and human niche construction: The potential role of Mesolithic hunter-gatherers in actively structuring Scotland's woodlands. Quaternary Science Reviews, 108(108), 51-75. https://doi.org/10.1016/j.quascirev.2014.11. 004.

Boethius, A. (2018). Fishing for ways to thrive. Integrating zooarchaeology to understand subsistence strategies and their implications among Early and Middle Mesolithic southern Scandinavian foragers. Studies in Osteology 4. Lund University.

Boivin, N., Zeder, M., Fuller, D., Crowther, A., Larson, G., Erlandson, J., et al. (2016). Ecological consequences of human niche construction: Examining long-term anthropogenic shaping of global species distributions. PNAS, 113(23), 6388-6396. http://www.pnas.org/cgi/doi/10.1073/pnas.15252 00113.

Bos, J. A. A., \& Urz, R. (2003). Late Glacial and early Holocene environment in the middle Lahn river valley (Hessen, central-west Germany) and the local impact of early Mesolithic people-pollen and macrofossil evidence. Vegetation History and Archaeobotany, 12, 19-36. https://doi.org/10. 1007/s00334-003-0006-7.

Boyd, M. (2002). Identification of anthropogenic burning in the paleoecological record of the northern prairies: a new approach. Annals of the Association of American Geographers, 92(3), 471-487. https://doi.org/10.1111/1467-8306.00300.

Braadbaart, F., Poole, I., \& van Brussel, A. A. (2009). Preservation potential of charcoal in alkaline environments: An experimental approach and implications for the archaeological record. Journal of Archaeological Science, 36, 1672-1679. https://doi.org/10.1016/j.jas.2009.03.006.

Braadbaart, F., Reidsma, F. H., Roebroeks, W., Chiotti, L., Slon, V., Meyer, M., et al. (2020). Heating histories and taphonomy of ancient fireplaces: A multi-proxy case study from the Upper Palaeolithic sequence of Abri Pataud (Les Eyzies-de- Tayac, France). Journal of Archaeological Science: Reports, 33. https://doi.org/10.1016/j.jasrep.2020.102468.

Brittingham, A., Hren, M. T., Hartman, G., Wilkinson, K. N., Mallol, C., Gasparyan, B., \& Adler, D. S. (2019). Geochemical evidence for the control of fire by Middle Palaeolithic hominins. Scientific Reports, 9. https://doi.org/10.1038/s41598-019-51433-0.

Britton, K., Gaudzinski-Windheuser, S., Roebroeks, W., Kindler, L., \& Richards, M. P. (2012). Stable isotope analysis of well-preserved 120,000-year-old herbivore bone collagen from the Middle Palaeolithic site of Neumark-Nord 2, Germany reveals niche separation between bovids and equids. Palaeogeography, Palaeoclimatology, Palaeoecology, 333 - 334, 168-177. https://doi.org/10.1016/j. palaeo.2012.03.028.

Britton, K., Pederzani, S., Kindler, L., Roebroeks, W., Gaudzinski-Windheuser, S., Richards, M. P., \& Tütken, T. (2019). Oxygen isotope analysis of Equus teeth evidences early Eemian and early Weichselian palaeotemperatures at the Middle Palaeolithic site of Neumark-Nord 2, SaxonyAnhalt, Germany. Quaternary Science Reviews, 226. https://doi.org/10.1016/j.quascirev.2019. 106029. 
Brodowski, S., Amelung, W., Haumaier, L., Abetz, C., \& Zech, W. (2005). Morphological and chemical properties of black carbon in physical soil fractions as revealed by scanning electron microscopy and energy-dispersive X-ray spectroscopy. Geoderma, 128(1-2), 116-129. https://doi.org/10. 1016/j.geoderma.2004.12.019.

Callaway, E. (2021). Million-year-old mammoth genomes shatter record for oldest ancient DNA. Nature. https://doi.org/10.1038/d41586-021-00436-x.

Campbell, S. K., \& Butler, V. L. (2010). Fishes and loaves? Explaining sustainable, long-term animal harvesting on the northwest coast using the "plant paradigm.". In C. Smith (Ed.), The Archaeology of Anthropogenic Environments (pp. 175-203). Center for Archaeological Investigations.

Castree, N. (2017). Anthropocene and planetary boundaries. In D. Richardson, N. Castree, M. F. Goodchild, A. Kobayashi, W. Liu, \& R. A. Marston (Eds.), Encyclopedia of Global Environmental Governance and Politics (pp. 161-174). John Wiley \& Sons.

Chen, X., Kang, S., Cong, Z., Yang, J., \& Ma, Y. (2018). Concentration, temporal variation, and sources of black carbon in the Mt. Everest region retrieved by real-time observation and simulation. Atmospheric Chemistry and Physics, 18(17), 12859-12875. https://doi.org/10.5194/acp-18-12859-2018.

Cortella, A. R., \& Pochettino, M. L. (1994). Starch grain analysis as a microscopic diagnostic feature in the identification of plant material. Economic Botany, 48. https://doi.org/10.1007/BF02908212.

Cristiani, E., Radini, A., Edinborough, M., \& Borić, D. (2016). Dental calculus reveals Mesolithic foragers in the Balkans consumed domesticated plant foods. PNAS, 113(37), 10298-10303. www.pnas. org/cgi/doi/10.1073/pnas.1603477113.

Crutzen, P. J. (2002). Geology of mankind. Nature, 415, 23. https://doi.org/10.1038/415023a.

Crutzen, P. J., \& Stoermer, E. F. (2000). The "Anthropocene". IGBP Newsletter, 41, 17-18.

Cugny, C., Mazier, F., \& Galop, D. (2010). Modern and fossil non-pollen palynomorphs from the Basque mountains (western Pyrenees, France): The use of coprophilous fungi to reconstruct pastoral activity. Vegetation History and Archaeobotany, 19, 391-408. https://doi.org/10.1007/ s00334-010-0242-6.

Cui, Q.-Y., Gaillard, M.-J., Lemdahl, G., Sugita, S., Greisman, A., Jacobson, G. L., \& Olsson, F. (2013). The role of tree composition in Holocene fire history of the hemiboreal and southern boreal zones of southern Sweden, as revealed by the application of the Landscape Reconstruction Algorithm: Implications for biodiversity and climate-change issues. The Holocene, 23(12), 1747-1763. https:// doi.org/10.1177/0959683613505339.

Daniau, A.-L., Goñi, M. F. S., \& Duprat, J. (2009). Last glacial fire regime variability in western France inferred from microcharcoal preserved in core MD04-2845, Bay of Biscay. Quaternary Research, 71(3), 385-396. https://doi.org/10.1016/j.yqres.2009.01.007.

Davies, P., Robb, J. G. R., \& Ladbrook, D. (2005). Woodland clearance in the Mesolithic: The social aspects. Antiquity, 79, 280-288.

Delcourt, H. (1987). The impact of prehistoric agriculture and land occupation on natural vegetation. Trends in Ecology \& Evolution, 2(2), 39-44.

Denham, T. P., Golson, J., \& Hughes, P. J. (2004). Reading early agriculture at Kuk Swamp, Wahgi Valley, Papua New Guinea: the Archaeological Features (Phases 1-3). Proceedings of the Prehistoric Society, 70, 259-297. https://doi.org/10.1017/S0079497X00001195.

Denis, E. H., Toney, J. L., Tarozo, R., Anderson, R. S., Roach, L. D., \& Huang, Y. (2012). Polycyclic aromatic hydrocarbons (PAHs) in lake sediments record historic fire events: Validation using HPLCfluorescence detection. Organic Geochemistry, 45, 7-17. https://doi.org/10.1016/j.orggeochem. 2012.01.005.

Deur, D., Dick, A., Recalma-Clutesi, K., \& Turner, N. J. (2015). Kwakwaka'wakw "Clam Gardens". Motive and Agency in Traditional Northwest Coast Mariculture. Human Ecology, 43, 201-212. https://doi.org/10.1007/s10745-015-9743-3.

Dibble, H. L., Sandgathe, D., Goldberg, P., McPherron, S., \& Aldeias, V. (2018). Were Western European Neanderlas able to Make Fire? Journal of Paleolithic Archaeology, 1, 54-79. https://doi.org/10. 1007/s41982-017-0002-6.

Dietze, E., Theuerkauf, M., Bloom, K., Brauer, A., Dörfler, W., Feeser, I., et al. (2018). Holocene fire activity during low-natural flammability periods reveals scale-dependent cultural human-fire relationships in Europe. Quaternary Science Reviews, 201(1), 44-56. https://doi.org/10.1016/j.quasc irev.2018.10.005.

Divišová, M., \& Šída, P. (2015). Plant use in the Mesolithic period. Archaeobotanical Data from the Czech Republic in a European Context - A review. Natural Sciences in Archaeology, 6(1), 95-106. 
Duffin, K. I., Gillson, L., \& Willis, K. J. (2008). Testing the sensitivity of charcoal as an indicator of fire events in savanna environments: Quantitative predictions of fire proximity, area and intensity. The Holocene, 18(2), 279-291. https://doi.org/10.1177/0959683607086766.

Dussex, N., Bergfeldt, N., de Prado, V. A., Dehasque, M., Díez-del-Molino, D., Ersmark, E., et al. (2021). Integrating multi-taxon palaeogenomes and sedimentary ancient DNA to study past ecosystem dynamics. Proceedings of the Royal Society B, 288(1957). https://doi.org/10.1098/RSPB.2021. 1252.

Eby, S. L., Anderson, M., Mayemba, E. P., \& Ritchie, M. E. (2014). The effect of fire on habitat selection of mammalian herbivores: the role of body size and vegetation characteristics. Journal of Animal Ecology, 83, 1196-1205. https://doi.org/10.1111/1365-2656.12221.

Ellis, E. C., Gauthier, N., Goldewijk, K. K., Bird, R. B., Boivin, N., Díaz, S., et al. (2021). People have shaped most of terrestrial nature for at least 12,000 years. Proceedings of the National Academy of Sciences of the United States of America, 118(17), 1-8. https://doi.org/10.1073/pnas.2023483118.

Ember, C. R. (2020). Hunter-gatherers. Explaining Human Culture. Human Relations Area Files. http:// hraf.yale.edu/ehc/summ. Accessed 9 December 2020.

Esteban, I., Marean, C. W., Fisher, E. C., Karkanas, P., Cabanes, D., \& Albert, R. M. (2018). Phytoliths as an indicator of early modern humans plant gathering strategies, fire fuel and site occupation intensity during the Middle Stone Age at Pinnacle Point 5-6 (south coast, South Africa). PLoS ONE, 13(6). https://doi.org/10.1371/journal.pone.0198558.

Feeney, J. (2019). Hunter-gatherer land management in the human break from ecological sustainability. Anthropocene Review, 6(3), 223-242. https://doi.org/10.1177/2053019619864382.

Finsinger, W., Tinner, W., van der Knaap, W. O., \& Ammann, B. (2006). The expansion of hazel (Corylus avellana L.) in the southern Alps: A key for understanding its early Holocene history in Europe? Quaternary Science Reviews, 25(5-6), 612-631. https://doi.org/10.1016/j.quascirev.2005.05.006.

Foster, N. R., Gillanders, B. M., Jones, A. R., Young, J. M., \& Waycott, M. (2020). A muddy time capsule: Using sediment environmental DNA for the long-term monitoring of coastal vegetated ecosystems. Marine and Freshwater Research. https://doi.org/10.1071/MF19175.

Fuller, D. Q., \& Lucas, L. (2014). Archaeobotany. In C. Smith (Ed.), Encyclopedia of Global Archaeology (pp. 305-309). Springer Science, Business Media.

Gaillard, M. J. (2013). Pollen Methods and Studies. Archaeological Applications. In S. Elias \& C. J. Mock (Eds.), Encyclopedia of Quaternary Science (Second ed., pp. 880-904). Elsevier.

Gaillard, M.-J., Birks, H. J. B., Emanuelsson, U., Karlsson, S., Lagerås, P., \& Olausson, D. (1994). Application of modern pollen/land-use relationships to the interpretation of pollen diagrams-Reconstructions of land-use history in south Sweden, 3000-0 BP. Review of Palaeobotany and Palynology, 82, 47-73. https://doi.org/10.1016/0034-6667(94)90019-1.

García-Moreno, A., Smith, G. M., Kindler, L., Pop, E., Roebroeks, W., Gaudzinski-Windheuser, S., \& Klinkenberg, V. (2016). Evaluating the incidence of hydrological processes during site formation through orientation analysis. A case study of the middle Palaeolithic Lakeland site of NeumarkNord 2 (Germany). Journal of Archaeological Science: Reports, 6, 82-93. https://doi.org/10. 1016/j.jasrep.2016.01.023.

Gaudzinski-Windheuser, S., Noack, E. S., Pop, E., Herbst, C., Pfleging, J., Buchli, J., et al. (2018). Evidence for close-range hunting by last interglacial Neanderthals. Nature Ecology and Evolution, 2, 1087-1092. https://doi.org/10.1038/s41559-018-0596-1.

Gaudzinski-Windheuser, S., \& Roebroeks, W. (Eds.) (2014). Multidisciplinary studies of the Middle Palaeolithic record from Neumark-Nord (Germany). Halle: Landesmuseum für Vorgeschichte.

Gelorini, V., Ssemmanda, I., \& Verschuren, D. (2012). Validation of non-pollen palynomorphs as paleoenvironmental indicators in tropical Africa: Contrasting 200-year paleolimnological records of climate change and human impact. Review of Palaeobotany and Palynology, 186, 90-101. https://doi.org/10.1016/j.revpalbo.2012.05.006.

Giguet-Covex, C., Pansu, J., Arnaud, F., Rey, P.-J., Griggo, C., Gielly, L., et al. (2014). Long livestock farming history and human landscape shaping revealed by lake sediment DNA. Nature. https://doi. org/10.1038/ncomms4211.

Giguet-Covex, C., Ficetola, G. F., Walsh, K., Poulenard, J., Bajard, M., Fouinat, L., et al. (2019). New insights on lake sediment DNA from the catchment: Importance of taphonomic and analytical issues on the record quality. Review of Palaeobotany and Palynology. https://doi.org/10.1038/ s41598-019-50339-1.

Gill, J. L., McLauchlan, K. K., Skibbe, A. M., Goring, S., Zirbel, C. R., \& Williams, J. W. (2013). Linking abundances of the dung fungus Sporormiella to the density of bison: Implications for assessing 
grazing by megaherbivores in palaeorecords. Journal of Ecology, 101(5), 1125-1136. https://doi. org/10.1111/1365-2745.12130.

Goldberg, P., Miller, C. E., \& Mentzer, S. M. (2017). Recognizing fire in the paleolithic archaeological record. Current Anthropology, 58. https://doi.org/10.1086/692729.

Gowlett, J. A. J., \& Wrangham, R. (2013). Earliest fire in Africa: Towards the convergence of archaeological evidence and the cooking hypothesis. Azania Archaeological Research in Africa, 48(1), 5-30. https://doi.org/10.1080/0067270X.2012.756754.

Greaves, R. D., \& Kramer, K. L. (2014). Hunter-gatherer use of wild plants and domesticates: Archaeological implications for mixed economies before agricultural intensification. Journal of Archaeological Science, 41, 263-271. https://doi.org/10.1016/j.jas.2013.08.014.

Greenwood, D. R. (1991). The taphonomy of plant macrofossils. In S. K. Donovan (Ed.), The Processes of Fossilization (pp. 141-169). Columbia University Press.

Groß, D., Piezonka, H., Corradini, E., Schmölcke, U., Zanon, M., Dörfler, W., et al. (2019). Adaptations and transformations of hunter-gatherers in forest environments: New archaeological and anthropological insights. The Holocene, 29(10), 1531-1544. https://doi.org/10.1177/0959683619857231.

Gumiński, W., \& Michniewicz, M. (2003). Forest and mobility. A case from the fishing camp Dudka, Masuria, north-eastern Poland. In L. Larsson (Ed.), Mesolithic on the Move. Papers presented at the Sixth International Conference on the Mesolithic in Europe (pp. 119-127). Oxbow Books.

Haas, J. N. (2010). Fresh insights into the palaeoecological and palaeoclimatological value of Quaternary non-pollen palynomorphs. Vegetation History and Archaeobotany, 19, 389. https://doi.org/10. 1007/s00334-010-0274-y.

Haile, J., Froese, D. G., MacPhee, R. D. E., Roberts, R. G., Arnold, L. J., Reyes, A. V., et al. (2009). Ancient DNA reveals late survival of mammoth and horse in interior Alaska. PNAS, 106(52), 22352-22357. https://doi.org/10.1073/pnas.0912510106.

Hamilton, R., Stevenson, J., Li, B., \& Bijaksana, S. (2019). A 16,000-year record of climate, vegetation and fire from Wallacean lowland tropical forests. Quaternary Science Reviews, 224(15). https://doi. org/10.1016/j.quascirev.2019.105929.

Hardy, B. L., \& Moncel, M.-H. (2011). Neanderthal use of fish, mammals, birds, starchy plants and wood 125-250,000 years ago. PLoS ONE, 6(8) https://doi.org/10.1371/journal.pone.0023768.

Hardy, K., Radini, A., Buckley, S., Sarig, R., Copeland, L., Gopher, A., \& Barkai, R. (2016). Dental calculus reveals potential respiratory irritants and ingestion of essential plant-based nutrients at Lower Palaeolithic Qesem Cave Israel. Quaternary International, 398, 129-135. https://doi.org/10.1016/j. quaint.2015.04.033.

Hardy, K., Radini, A., Buckley, S., Blasco, R., Copeland, L., Burjachs, F., et al. (2017). Diet and environment 1.2 million years ago revealed through analysis of dental calculus from Europe's oldest hominin at Sima del Elefante, Spain The Science of Nature, 104(2). https://doi.org/10.1007/ s00114-016-1420-x.

Harris, D. R. (2013). Plant Domestications. In V. Cummings, P. Jordan, \& M. Zvelebil (Eds.), The Oxford Handbook of the Archaeology and Anthropology of Hunter-Gatherers (pp. 729-749). Oxford University Press.

Harrower, M. J. (2016). Water histories and spatial archaeology. Cambridge University Press.

Hellman, S., Bunting, M. J., \& Gaillard, M.-J. (2009). Relevant source area of pollen in patchy cultural landscapes and signals of anthropogenic landscape disturbance in the pollen record: A simulation approach. Review of Palaeobotany and Palynology, 153, 245-258. https://doi.org/10.1016/j.revpa lbo.2008.08.006.

Henry, A., Théry-Parisot, I., \& Voronkova, E. (2008). La gestion du bois de feu en forêt boréale: archéoanthracologie et ethnographie (région de l'Amour, Sibérie). In A. Théry-Parisot, I. Costamagno, \& S. Henry (Eds.), Actes du XV Congrès mondial de l'Union Internationale des Sciences Préhistoriques et Protohistoriques. Gestion des combustibles au Paléolithique et au Mésolithique nouveaux outils, nouvelles interprétations (pp. 13-33). Archaeopress.

Henry, A. G., Brooks, A. S., \& Piperno, D. R. (2011). Microfossils in calculus demonstrate consumption of plants and cooked foods in Neanderthal diets (Shanidar III, Iraq; Spy I and II, Belgium). PNAS, 108(2), 486-491. www.pnas.org/cgi/doi/10.1073/pnas.1016868108.

Henry, A. G., Brooks, A. S., \& Piperno, D. R. (2014). Plant foods and the dietary ecology of Neanderthals and early modern humans. Journal of Human Evolution, 69, 44-54. https://doi.org/10.1016/j. jhevol.2013.12.014. 
Herzog, N. M., Keefe, E. R., Parker, C. H., \& Hawkes, K. (2016). What's burning got to do with it? Primate foraging opportunities in fire-modified landscapes. American Journal of Physical Anthropology, 159, 432-441. https://doi.org/10.1002/ajpa.22885.

Hicks, S. (1992). Modern pollen deposition and its use in interpreting the occupation history of the island Hailuoto, Finland. Vegetation History and Archaeobotany, 1, 75-86.

Hicks, S., \& Birks, H. J. B. (1996). Numerical analysis of modern and fossil pollen spectra as a tool for elucidating the nature of fine-scale human activities in boreal areas. Vegetation History and Archaeobotany, 5, 257-272.

Hitchcock, R. K. (2019). Hunters and gatherers past and present: Perspectives on diversity, teaching, and information transmission. Reviews in Archaeology, 48(1), 5-37. https://doi.org/10.1080/00938157. 2019.1578025 .

Hjelle, K. L., \& Lødøen, T. K. (2017). Dating of rock art and the effect of human activity on vegetation: The complementary use of archaeological and scientific methods. Quaternary Science Reviews, 168(15), 194-207. https://doi.org/10.1016/j.quascirev.2017.05.003.

Holst, D. (2010). Hazelnut economy of early Holocene hunter-gatherers: A case study from Mesolithic Duvensee, northern Germany. Journal of Archaeological Science, 37(11), 2871-2880. https://doi. org/10.1016/j.jas.2010.06.028.

Hoppe, K. A. (2004). Late Pleistocene mammoth herd structure, migration patterns, and Clovis hunting strategies inferred from isotopic analyses of multiple death assemblages. Paleobiology, 30(1), $129-145$.

Hörnberg, G., Bohlin, E., Hellberg, E., Bergman, I., Zackrisson, O., Olofsson, A., et al. (2006). Effects of Mesolithic hunter-gatherers on local vegetation in a non-uniform glacio-isostatic land uplift area, northern Sweden. Vegetation History and Archaeobotany, 15, 13-26. https://doi.org/10.1007/ s00334-005-0006-x.

Huang, X., Zhang, J., Storozum, M., Liu, S., Gill, L. J., Xiang, L., et al. (2020). Long-term herbivore population dynamics in the northeastern Qinghai-Tibet Plateau and its implications for early human impacts. Review of Palaeobotany and Palynology, 275. https://doi.org/10.1016/j.revpalbo. 2020.104171.

Innes, J. B., \& Blackford, J. J. (2003). The ecology of late Mesolithic woodland disturbances: Model testing with fungal spore assemblage data. Journal of Archaeological Science, 30(2), 185-194. https:// doi.org/10.1006/jasc.2002.0832.

Innes, J. B., \& Blackford, J. J. (2017). Palynology and the study of the Mesolithic-Neolithic transition in the British Isles. The archaeological and forensic applications of microfossils: a deeper understanding of human history, 7. https://doi.org/10.1144/TMS007.

Innes, J. B., Blackford, J. J., \& Simmons, I. G. (2004). Testing the integrity of fine spatial resolution palaeoecological records: Microcharcoal data from near-duplicate peat profiles from the North York Moors, UK. Palaeogeography, Palaeoclimatology, Palaeoecology, 214(4), 295-307. https://doi. org/10.1016/j.palaeo.2004.04.004.

Innes, J. B., Blackford, J. J., \& Rowley-Conwy, P. A. (2013). Late Mesolithic and early Neolithic forest disturbance: A high resolution palaeoecological test of human impact hypotheses. Quaternary Science Reviews, 77, 80-100. https://doi.org/10.1016/j.quascirev.2013.07.012.

Jackson, S., \& Barber, M. (2016). Historical and contemporary waterscapes of North Australia: Indigenous attitudes to dams and water diversions. Water History, 8, 385-404. https://doi.org/10.1007/ s12685-016-0168-8.

Kaal, J., Martínez Cortizas, A., Eckmeier, E., Costa Casais, M., Santos Estévez, M., \& Criado Boado, F. (2008a). Holocene fire history of black colluvial soils revealed by pyrolysis-GC/MS: A case study from Campo Lameiro (NW Spain). Journal of Archaeological Science, 35(8), 2133-2143. https:// doi.org/10.1016/j.jas.2008.01.013.

Kaal, J., Martinez-Cortizas, A., Buurman, P., \& Criado Boado, F. (2008b). 8000 yr of black carbon accumulation in a colluvial soil from NW Spain. Quaternary Research, 69(1), 56-61. https://doi.org/ 10.1016/j.yqres.2007.10.005.

Kaal, J., Carrión Marco, Y., Asouti, E., Martín Seijo, M., Martínez Cortizas, A., Costa Casáis, M., \& Criado Boado, F. (2011). Long-term deforestation in NW Spain: Linking the Holocene fire history to vegetation change and human activities. Quaternary Science Reviews, 30(1-2), 161-175. https:// doi.org/10.1016/j.quascirev.2010.10.006.

Kaal, J., Criado-Boado, F., Costa-Casais, M., López-Sáez, J. A., López-Merino, L., Mighall, T., et al. (2013). Prehistoric land use at an archaeological hot-spot (the rock art park of Campo Lameiro, 
NW Spain) inferred from charcoal, synanthropic pollen and non-pollen palynomorph proxies. Journal of Archaeological Science, 40(3), 1518-1527. https://doi.org/10.1016/j.jas.2012.09.024.

Kaplan, J. O., Pfeiffer, M., Kolen, J. C. A., \& Davis, B. A. S. (2016). Large scale anthropogenic reduction of forest cover in last glacial maximum Europe. PLoS ONE. https://doi.org/10.1371/journal.pone. 0166726.

Kehrwald, N., Zangrando, R., Gabrielli, P., Jaffrezo, J.-L., Boutron, C., Barbante, C., \& Gambaro, A. (2012). Levoglucosan as a specific marker of fire events in Greenland snow. Tellus Series B: Chemical and Physical Meteorology, 64. https://doi.org/10.3402/tellusb.v64i0.18196.

Kelly, R. L. (2013). The lifeways of hunter-gatherers: The foraging spectrum. Cambridge University Press.

Khomich, L.V. (1966) Nency. Istoriko-etnograficheskie ocherki. (Nenets. Historical and ethnographic essays). Nauka.

Kindler, L., Smith, G., \& Wagner, M. (2014). Introduction to faunal analysis at Neamark-Nord 2. In S. Gaudzinski-Windheuser \& W. Roebroeks (Eds.), Multidisciplinary studies of the Middle Palaeolithic record from Neumark-Nord (Germany) (pp. 197-211). Landesmuseum für Vorgeschichte.

Kindler, L., Smith, G. M., García-Moreno, A., Gaudzinski-Windheuser, S., Pop, E., \& Roebroeks, W. (2020). The Last Interglacial (Eemian) lakeland at Neumark-Nord (Saxony-Anhalt, Germany). Sequencing Neanderthal occupations, assessing subsistence opportunities and prey selection based on estimations of ungulate carrying capacities, biomass production and energy values. In A. García-Moreno, J. M. Hutson, G. M. Smith, L. Kindler, E. Turner, A. Villaluenga, \& S. Gaudzinski-Windheuser (Eds.), Human behavioural adaptations to interglacial lakeshore environments (pp. 67-105). Propylaeum.

Kintigh, K. W., Altschul, J. H., Beaudry, M. C., Drennan, R. D., Kinzing, A. P., Kohler, T. A., et al. (2014). Grand challenges for archaeology. PNAS, 111(3), 879-880. https://doi.org/10.1073/pnas. 1324000111.

Kirch, P. V. (2005). Archaeology and global change: The Holocene record. Annual Review of Environment and Resources, 30, 409-440. https://doi.org/10.1146/annurev.energy.29.102403.140700.

Klooss, S., Fischer, E., Out, W., \& Kirleis, W. (2016). Charred root tubers of lesser celandine (Ficaria verna HUDS.) in plant macro remain assemblages from Northern, Central and Western Europe. Quaternary International, 404(A), 25-42. https://doi.org/10.1016/j.quaint.2015.10.014.

Komarek, E. V. (1969). Fire and animal behavior. Proceedings of 9th Tall Timbers Fire Ecology Conference, 9, 160-207.

Kotthoff, U., Koutsodendris, A., Pross, J., Schmiedl, G., Bornemann, A., Kaul, C., et al. (2011). Impact of Lateglacial cold events on the northern Aegean region reconstructed from marine and terrestrial proxy data. Journal of Quaternary Science, 26(1), 86-96. https://doi.org/10.1002/jqs.1430.

Kovárník, J., \& Beneš, J. (2018). Microscopic analysis of starch grains and its applications in the archaeology of the Stone Age. Interdisciplinaria Archaeologica. Natural Sciences in Archaeology, 9(1), 83-93. https://doi.org/10.24916/iansa.2018.1.6.

Kubiak-Martens, L. (1996). Evidence for possible use of plant foods in Palaeolithic and Mesolithic diet from the site of Całowanie in the central part of the Polish Plain. Vegetation History and Archaeobotany, 5, 33-38.

Kubiak-Martens, L. (2002). New evidence for the use of root foods in pre-agrarian subsistence recovered from the late Mesolithic site at Halsskov, Denmark. Vegetation History and Archaeobotany, 11(1), 23-32. https://doi.org/10.1007/s003340200003.

Kubiak-Martens, L. (2015). Mesolithic diet. In K. B. Metheny \& M. C. Beaudry (Eds.), Archaeology of food (pp. 312-316). Rowman \& Littlefield.

Kuijper, W. (2014). Investigation of inorganic, botanical, and zoological remains of an exposure of Last Interglacial (Eemian) sediments at Neumark-Nord 2 (Germany). In S. Gaudzinski-Windheuser \& W. Roebroeks (Eds.), Multidisciplinary studies of the Middle Palaeolithic record from NeumarkNord (Germany) (pp. 79-96). Landesmuseum für Vorgeschichte.

Landon, D. B. (2005). Zooarchaeology and historical archaeology: Progress and prospects. Journal of Archaeological Method and Theory, 12. https://doi.org/10.1007/s10816-005-2395-7.

Lane, P. J. (2015). Archaeology in the age of the Anthropocene: A critical assessment of its scope and societal contributions. Journal of Field Archaeology, 40(5), 485-498. https://doi.org/10.1179/ 2042458215Y.0000000022.

Ledger, P. M. (2018). Are circumpolar hunter-gatherers visible in the palaeoenvironmental record? Pollen-analytical evidence from Nunalleq, southwestern Alaska. The Holocene, 28(3), 415-426. https://doi.org/10.1177/0959683617729447. 
Lewis, S. L., \& Maslin, M. A. (2015). Defining the Anthropocene. Nature, 519, 171-180. https://doi.org/ 10.1038 /nature 14258 .

Lightfoot, K. G., Cuthrell, R. Q., Striplen, C. J., \& Hylkema, M. G. (2013). Rethinking the study of landscape management practices among hunter-gatherers in North America. American Antiquity, 78(2), 285-301. https://doi.org/10.7183/0002-7316.78.2.285.

Lindholm, K.-J., Fernández, N., Svenning, J.-C., Pereira, H., \& Kluiving, S. J. (2020). Terranova White Paper 1: Policy recommendations for sustainable landscape management strategies. https://doi.org/ 10.5281/zenodo.4015030.

Liu, L., Bestel, S., Shi, J., Song, Y., \& Chen, X. (2013). Paleolithic human exploitation of plant foods during the last glacial maximum in North China. PNAS, 110(14), 5380-5385. www.pnas.org/cgi/ doi/10.1073/pnas.1217864110.

Loughlin, N. J. D., Gosling, W. D., \& Montoya, E. (2018). Identifying environmental drivers of fungal non-pollen palynomorphs in the montane forest of the eastern Andean flank, Ecuador. Quaternary Research, 89, 119-133. https://doi.org/10.1017/qua.2017.73.

Lozovski, V. M., \& Lozovskaya, O. V. (2016). New evidence of the fishing economy of Stone Age waterlogged sites in Central and North-Western Russia: The example of Zamostje 2. New Sites, New Methods, Proceedings of the Finnish-Russian Archaeological Symposium, Iskos, 21, 85-100.

Lozovski, V. M., Lozovskaya, O. V., \& Clemente Conte, I. (Eds.). (2013). Zamostje 2. Lake settlement of the Mesolithic and Neolithic fisherman in Upper Volga region. Institute for the History of Material Culture.

Lytwyn, V. (2001). Torchlight prey: Night hunting and fishing by aboriginal people in the Great Lakes Region. In J. D. Nichols (Ed.), Actes du trente-deuxiéme congrès des algonquinistes (Vol. 32, pp. 304-317). University of Manitoba.

Mania, D. (2010). Neumark-Nord. Ein interglaziales Ökosystem des mittelpaläolithischen Menschen. Landesamt für Denkmalpflege und Archäologie Sachsen-Anhalt.

Mania, D., Thomae, M., Litt, T., \& Weber, T. (1990). Neumark-Gröbern: Beiträge Zur Jagd Des Mittelpaläolithischen Menschen (Vol. 43, pp. 9-113). Veröffentlichungen Des Landesmuseums Für Vorgeschichte in Halle.

Mann, D. H., Groves, P., Gaglioti, B. V., \& Shapiro, B. A. (2019). Climate-driven ecological stability as a globally shared cause of Late Quaternary megafaunal extinctions: The Plaids and Stripes Hypothesis. Biological Reviews, 94, 328-352. https://doi.org/10.1111/brv.12456.

Mariotti Lippi, M., Foggi, B., Aranguren, B., Ronchitelli, A., \& Revedin, A. (2015). Multistep food plant processing at Grotta Paglicci (Southern Italy) around 32,600 cal B.P. PNAS, 112(39), 1207512080. www.pnas.org/cgi/doi/10.1073/pnas.1505213112.

Martín-Puertas, C., Jiménez-Espejo, F., Martínez-Ruiz, F., Nieto-Moreno, V., Rodrigo, M., Mata, M. P., \& Valero-Garcés, B. L. (2010). Late Holocene climate variability in the southwestern Mediterranean region: An integrated marine and terrestrial geochemical approach. Climate of the Past, 6 , 807-816. https://doi.org/10.5194/cp-6-807-2010.

Mason, S. L. R. (2000). Fire and Mesolithic subsistence - Managing oaks for acorns in northwest Europe? Palaeogeography, Palaeoclimatology, Palaeoecology, 164(1-4), 139-150. https://doi.org/ 10.1016/S0031-0182(00)00181-4.

Mazier, F., Galop, D., Brun, C., \& Buttler, A. (2006). Modern pollen assemblages from grazed vegetation in the western Pyrenees, France: A numerical tool for more precise reconstruction of past cultural landscapes. The Holocene, 16(1), 91-103. https://doi.org/10.1191/0959683606hl908rp.

Mazier, F., Galop, D., Gaillard, M. J., Rendu, C., Cugny, C., Legaz, A., et al. (2009). Multidisciplinary approach to reconstructing local pastoral activities: An example from the Pyrenean Mountains (Pays Basque). The Holocene, 19(2), 171-188. https://doi.org/10.1177/0959683608098956.

McKey, D. B., Durécu, M., Pouilly, M., Béarez, P., Ovando, A., Kalebe, M., \& Huchzermeyer, C. F. (2016). Present-day African analogue of a pre-European Amazonian floodplain fishery shows convergence in cultural niche construction. PNAS, 113(52), 14938-14943. www.pnas.org/cgi/doi/10. 1073/pnas.1613169114.

McQuade, M., \& O’Donnell, L. (2007). Late Mesolithic fish traps from the Liffey estuary, Dublin, Ireland. Antiquity, 81(313), 569-584. https://doi.org/10.1017/S0003598X00095594.

Mellars, P. (1976). Fire ecology, animal populations and man: A study of some ecological relationships in prehistory. Proceedings of the Prehistoric Society, 42, 15-45.

Mellars, P., \& Dark, P. (Eds.). (1998). Star Carr in context: New archaeological and palaeoecolgical investigations at the early Mesolithic site of Star Carr, North Yorkshire. McDonald Institute Monographs. 
Meller, H. (2010). Elefantenreich. Eine Fossilwelt in Europa. Landesamt für Denkmalpflege une Archäologie Sachsen-Anhalt - Landesmuseum für Vorgeschichte.

Menozzi, B. I., Zotti, M., \& Montanari, C. (2010). A non-pollen palynomorphs contribution to the local environmental history in the Ligurian Apennines: A preliminary study. Vegetation History and Archaeobotany, 19, 503-512. https://doi.org/10.1007/s00334-010-0271-1.

Messner, T. C., Dickau, R., \& Harbison, J. (2008). Starch grain analysis: Methodology and applications in the northeast. In J. P. Hart (Ed.), Current Northeast Paleothnobotany II (pp. 111-128). New York State Museum.

Milano, S., Pop, E., Kuijper, W., Roebroeks, W., Gaudzinski-Windheuser, S., Penkman, K., et al. (2020). Environmental conditions at the Last Interglacial (Eemian) site Neumark-Nord 2, Germany inferred from stable isotope analysis of freshwater mollusc opercula. Boreas, 49(3), 477-487. https://doi. org/10.1111/bor. 12437 .

Milner, N., Conneller, C., \& Taylor, B. (2018). Star Carr: A persistent place in a changing world. White Rose University Press.

Montgomery, P., Forsythe, W., \& Breen, C. (2015). Intertidal fish traps from Ireland: some recent discoveries in Lough Swilly, Co. Donegal. Journal of Maritime Archaeology, 10, 117-139. https://doi. org/10.1007/s11457-015-9146-Z.

Morris, H., Plavcová, L., Cvecko, P., Fichtler, E., Gillingham, M. A. F., Martínez-Cabrera, H. I., et al. (2016). A global analysis of parenchyma tissue fractions in secondary xylem of seed plants. New Phytologist, 209, 1553-1565. https://doi.org/10.1111/nph.13737.

Nielsen, A. B., \& Odgaard, B. V. (2010). Quantitative landscape dynamics in Denmark through the last three millennia based on the Landscape Reconstruction Algorithm approach. Vegetation History and Archaeobotany, 19, 375-387. https://doi.org/10.1007/s00334-010-0249-z.

Nielsen, A. B., Giesecke, T., Theuerkauf, M., Feeser, I., Behre, K. E., Beug, H.-J., et al. (2012). Quantitative reconstructions of changes in regional openness in north-central Europe reveal new insights into old questions. Quaternary Science Reviews, 47, 131-149. https://doi.org/10.1016/j.quascirev. 2012.05.011.

Nielsen, T. K., Benito, B. M., Svenning, J.-C., Sandel, B., McKerracher, L., Riede, F., \& Kjaergaard, P. C. (2015). Investigating Neanderthal dispersal above $55 \mathrm{~N}$ in Europe during the Last Interglacial Complex. Quaternary International, 431B, 88-103. https://doi.org/10.1016/j.quaint.2015.10.039.

Niemeyer, B., Epp, L. S., Stoof-Leichsenring, K. R., Pestryakova, L. A., \& Herzschuh, U. (2017). A comparison of sedimentary DNA and pollen from lake sediments in recording vegetation composition at the Siberian treeline. Molecular Ecology Resources. https://doi.org/10.1111/1755-0998.12689.

O'Shea, J. M., \& Meadows, G. A. (2009). Evidence for early hunters beneath the Great Lakes. PNAS, 106(25), 10120-10123. https://doi.org/10.1073/pnas.0902785106.

Odling-Smee, J., Erwin, D. H., Palkovacs, E. P., Feldman, M. W., \& Laland, K. N. (2013). Niche construction theory: A practical guide for ecologists. The Quarterly Review of Biology, 88(1). https:// doi.org/10.1086/669266.

Oldfield, F., \& Dearing, J. A. (2003). The role of human activities in past environmental change. In K. D. Alverson, T. F. Pedersen, \& R. S. Bradley (Eds.), The Role of Human Activities in Past Environmental Change (pp. 143-162). Springer.

Osipowicz, G. (2019). Plant processing in the Late Mesolithic Poland: In search for function of the mysterious 'curved knives'. Archaeological and Anthropological Sciences, 11, 3613-3628. https://doi. org/10.1007/s12520-019-00784-w.

Out, W. A., Vermeeren, C., \& Hänninen, K. (2013). Branch age and diameter: Useful criteria for recognising woodland managementin the present and past? Journal of Archaeological Science, 40(11), 4083-4097. https://doi.org/10.1016/j.jas.2013.05.004.

Parducci, L., Jørgensen, T., Tollefsrud, M. M., Elverland, E., Alm, T., Fontana, S. L., et al. (2012). Glacial survival of Boreal Trees in Northern Scandinavia. Science, 335, 1083-1086. https://doi.org/10. $1126 /$ science. 1216043 .

Pascoe, B. (2014). Dark Emu. Black seeds: Agriculture or accident? Magabala Books.

Piperno, D. R., \& Stothert, K. E. (2003). Phytolith Evidence for Early Holocene Cucurbita Domestication in Southwest Ecuador. Science, 299(5609), 1054-1057. https://doi.org/10.1126/science.1080365.

Piperno, D. R., Weiss, E., Holst, I., \& Nadel, D. (2004). Processing of wild cereal grains in the Upper Palaeolithic revealed by starch grain analysis. Nature, 430(7000), 670-673. https://doi.org/10. 1038/nature02734. 
Piperno, D. R., Ranere, A. J., Holst, I., Iriarte, J., \& Dickau, R. (2009). Starch grain and phytolith evidence for early ninth millennium B.P. maize from the Central Balsas River Valley, Mexico. PNAS, 106(13), 5019-5024. https://doi.org/10.1073/pnas.0812525106.

Pop, E. (2014). Analysis of the Neumark-Nord 2/2 lithic assemblage: Results and interpretations. In S. Gaudzinski-Windheuser \& W. Roebroeks (Eds.), Multidisciplinary studies of the Middle Palaeolithic record from Neumark-Nord (Germany) (pp. 143-197). Landesmuseum für Vorgeschichte.

Pop, E., \& Bakels, C. (2015). Semi-open environmental conditions during phases of hominin occupation at the Eemian Interglacial basin site Neumark-Nord 2 and its wider environment. Quaternary Science Reviews, 117, 72-81. https://doi.org/10.1016/j.quascirev.2015.03.020.

Pop, E., Kuijper, W., van Hees, E., Smith, G., García-Moreno, A., Kindler, L., et al. (2016). Fires at Neumark-Nord 2, Germany: An analysis of fire proxies from a Last Interglacial Middle Palaeolithic basin site. Journal of Field Archaeology, 41(5), 603-617. https://doi.org/10.1080/00934690.2016. 1208518.

Pop, E., Charalampopoulos, D., Arps, C. S., Verbaas, A., Roebroeks, W., Gaudzinski-Windheuser, S., \& Langejans, G. (2018). Middle Palaeolithic percussive tools from the Last Interglacial Site Neumark-Nord 2/2 (Germany) and the visibility of such tools in the archaeological record. Journal of Paleolithic Archaeology, 1, 81-106. https://doi.org/10.1007/s41982-018-0008-8.

Price, G. J., Ferguson, K. J., Webb, G. E., Feng, Y., Higgins, P., Nguyen, A. D., et al. (2017). Seasonal migration of marsupial megafauna in Pleistocene Sahul (Australia-New Guinea). Proceedings of the Royal Society, 284. https://doi.org/10.1098/rspb.2017.0785.

Pryor, A. J. E., Steele, M., Jones, M. K., Svoboda, J., \& Beresford-Jones, D. G. (2013). Plant foods in the Upper Palaeolithic at Dolní Věstonice? Parenchyma redux. Antiquity, 87(338), 971-984. https:// doi.org/10.1017/S0003598X00049802.

Pryor, A. J. E., Pullen, A., Beresford-Jones, D. G., Svoboda, J. A., \& Gamble, C. S. (2016). Reflections on Gravettian firewood procurement near the Pavlov Hills, Czech Republic. Journal of Anthropological Archaeology, 43, 1-12. https://doi.org/10.1016/j.jaa.2016.05.003.

Ramachandran, S., \& Kedia, S. (2010). Black carbon aerosols over an urban region: Radiative forcing and climate impact. Journal of Geophysical Research, 115. https://doi.org/10.1029/2009JD013560.

Rawlence, N. J., Lowe, D. J., Wood, J. R., Young, J. M., Churchman, G. L., Huang, Y.-T., \& Cooper, A. (2014). Using palaeoenvironmental DNA to reconstruct past environments: Progress and prospects. Journal of Quaternary Science, 29(7), 610-626. https://doi.org/10.1002/jqs.2740.

Regnell, M. (2012). Plant subsistence and environment at the Mesolithic site Tågerup, southern Sweden: New insights on the "Nut Age.". Vegetation History and Archaeobotany, 21. https://doi.org/10. 1007/s00334-011-0299-x.

Regnell, M., Gaillard, M. J., Bartholin, T. S., \& Karsten, P. (1995). Reconstruction of environment and history of plant use during the late Mesolithic (Ertebølle culture) at the inland settlement of Bökeberg III, southern Sweden. Vegetation History and Archaeobotany, 4, 67-91.

Reid, R. (2012). Savannas of our birth: people, wildlife, and change in East Africa. University of California Press.

Revedin, A., Aranguren, B., Becattini, R., Longo, L., Marconi, E., Lippi, M. M., et al. (2010). Thirty thousand-year-old evidence of plant food processing. PNAS, 107(44). www.pnas.org/cgi/doi/10. 1073/pnas.1006993107.

Revelles, J., \& van Geel, B. (2016). Human impact and ecological changes in lakeshore environments. The contribution of non-pollen palynomorphs in Lake Banyoles (NE Iberia). Review of Palaeobotany and Palynology. https://doi.org/10.1016/j.revpalbo.2016.05.004.

Roberts, N., Fyfe, R. M., Woodbridge, J., Gaillard, M.-J., Davis, B. A. S., Kaplan, J. O., et al. (2018). Europe's lost forests: A pollenbased synthesis for the last 11,000 years. Scientific Reports, 8 . https://doi.org/10.1038/s41598-017-18646-7.

Roebroeks, W., \& Bakels, C. (2015). "Forest furniture" or "forest managers"? On Neanderthal presence in last interglacial environment. In F. Coward, R. Hosfield, M. Pope, \& F. Wenban-Smith (Eds.), Settlement, Society and Cognition in Human Evolution. Landscapes in mind (pp. 174-188). Cambridge University Press.

Roebroeks, W., \& Speleers, B. (2002). Last interglacial (eemian) occupation of the North European plain and adjacent areas. In A. Tuffreau \& W. Roebroeks (Eds.), Le Dernier Interglaciaire et les occupations humaines du Paléolithique moyen (pp. 31-40). Centre d'Etudes et de Recherches Préhistoriques; Université des Sciences et Technologies de Lille.

Roebroeks, W., \& Villa, P. (2011). On the earliest evidence for habitual use of fire in Europe. PNAS, 108(13), 5209-5214. www.pnas.org/cgi/doi/10.1073/pnas.1018116108. 
Roebroeks, W., MacDonald, K., Scherjon, F., Bakels, B., Kindler, L., Nikulina, A., Pop, E., \& Gaudzinski-Windheuser, S. Landscape modification by Last Interglacial Neanderthals. Science Advances (in press).

Roos, C. I., Zedeño, M. N., Hollenback, K. L., \& Erlick, M. M. H. (2018). Indigenous impacts on North American Great Plains fire regimes of the past millennium. PNAS, 115(32), 8143-8148. www. pnas.org/cgi/doi/10.1073/pnas.1805259115.

Rosen, A. M., \& Weiner, S. W. (1994). Identifying ancient irrigation: A new method using opaline phytoliths from emmer wheat. Journal of Archaeological Science, 21, 125-132.

Rovner, I. (2001). Cultural behavior and botanical history: phytolith analysis in small places and marrow intervals. In J. D. Meunier \& F. Colin (Eds.), Phytoliths: Applications in Earth Sciences and Human History (pp. 119-128). Zeitlinger Publishers.

Rowley-Conwy, P. A., \& Layton, R. (2011). Foraging and farming as niche construction: Stable and unstable adaptations. Philosophical Transactions of the Royal Society, 366, 849-862. https://doi. org/10.1098/rstb.2010.0307.

Ruddiman, W. F. (2013). The Anthropocene. The Annual Review of Earth and Planetary Sciences, 41, 45-68. https://doi.org/10.1146/annurev-earth-050212-123944.

Ryan, P. A., \& Blackford, J. J. (2010). Late Mesolithic environmental change at Black Heath, south Pennines, UK: A test of Mesolithic woodland management models using pollen, charcoal and nonpollen palynomorph data. Vegetation History and Archaeobothany, 19, 545-558. https://doi.org/10. 1007/s00334-010-0263-1.

Sandgathe, D. M., Dibble, H. L., Goldberg, P., McPherron, S. P., Turq, A., Niven, L., \& Hodgkins, J. (2011). Timing of the appearance of habitual fire use. PNAS, 108(29). https://doi.org/10.1073/pnas. 1106759108.

Sandom, C. J., Ejrnaes, R., Hansen, M. D. D., \& Svenning, J.-C. (2014a). High herbivore density associated with vegetation diversity in interglacial ecosystems. PNAS, 111(11), 4162-4167. www.pnas. org/cgi/doi/10.1073/pnas.1311014111.

Sandom, C. J., Faubry, S., Sandel, B. S., \& Svenning, J.-C. (2014b). Global late Quaternary megafauna extinctions linked to humans, not climate change. PNAS, 281. https://doi.org/10.1098/rspb.2013. 3254.

Sang, X. F., Gensch, I., Kammer, B., Khan, A., Kleist, E., Laumer, W., et al. (2016). Chemical stability of levoglucosan: An isotopic perspective. Geophysical Research Letters. https://doi.org/10.1002/ 2016 GL069179.

Scherjon, F., Bakels, C., MacDonald, K., \& Roebroeks, W. (2015). Burning the land an ethnographic study of off-site fire use by current and historically documented foragers and implications for the interpretation of past fire practices in the landscape. Current Anthropology, 56(3), 299-326. https:// doi.org/10.1086/681561.

Schlumbaum, A., Tensen, M., \& Jaenicke-Després, V. (2008). Ancient plant DNA in archaeobotany. Vegetation History and Archaeobotany, 17, 233-244. https://doi.org/10.1007/s00334-007-0125-7.

Schreuder, L. T., Hopmans, E. C., Castañeda, I. S., Schefuß, E., Mulitza, S., Damsté, J. S. S., \& Schouten, S. (2019). Late Quaternary biomass burning in Northwest Africa and interactions with climate, vegetation, and humans. Paleoceanography and Paleoclimatology, 34, 153-163. https://doi.org/10. 1029/2018PA003467.

Schreve, D. (2019). All is flux: The predictive power of fluctuating Quaternary mammalian faunalclimate scenarios. Philosophical Transactions of the Royal Society, B: Biological Sciences, 374. https://doi.org/10.1098/rstb.2019.0213.

Scott, A. C. (2000). The Pre-Quaternary history of fire. Palaeogeography, Palaeoclimatology, Palaeoecology, 164, 281-329. https://doi.org/10.1016/S0031-0182(00)00192-9.

Seddon, A. W. R., Mackay, A. W., Baker, A. G., Birks, J. B. H., Breman, E., Buck, C. E., et al. (2014). Looking forward through the past: Identification of 50 priority research questions in palaeoecology. Journal of Ecology, 102(1), 256-267. https://doi.org/10.1111/1365-2745.12195.

Sier, M. J., Roebroeks, W., Bakels, C. C., Dekkers, M. J., Brühl, E., De Loecker, D., et al. (2011). Direct terrestrial-marine correlation demonstrates surprisingly late onset of the last interglacial in central Europe. Quaternary Research, 75(1), 213-218. https://doi.org/10.1016/j.yqres.2010.11.003.

Simmons, I. G. (1996). The environmental impact of Later Mesolithic cultures: The creation of Moorland Landscape in England and Wales. Edinburgh University Press.

Smith, D. B. (2011). General patterns of niche construction and the management of 'wild' plant and animal resources by small-scale pre-industrial societies. Philosophical Transactions of the Royal Society, 366, 836-848. https://doi.org/10.1098/rstb.2010.0253. 
Smith, B. D., \& Zeder, M. A. (2013). The onset of the Anthropocene. Anthropocene, 4, 8-13. https://doi. org/10.1016/j.ancene.2013.05.001.

Smith, L. M., Garvey, R., \& Carlson, E. S. (2013). Hunter-gatherer subsistence variation and intensification. In C. Smith (Ed.), Encyclopedia of Global Archaeology (pp. 3578-3586). Springer.

Smith, F. A., Smith, R. E. E., Lyons, S. K., \& Payne, J. L. (2018). Body size downgrading of mammals over the late Quaternary. Science, 360, 310-313. https://doi.org/10.1126/science.aao5987.

Snir, A., Nadel, D., Groman-Yaroslavski, I., Melamed, Y., Sternberg, M., Bar-Yosef, O., \& Weiss, E. (2015). The origin of cultivation and proto-weeds, long before Neolithic farming. PLoS ONE. https://doi.org/10.1371/journal.pone.0131422.

Solheim, S., Fossum, G., \& Knutsson, H. (2018). Use-wear analysis of Early Mesolithic flake axes from South-eastern Norway. Journal of Archaeological Science: Reports, 17, 560-570. https://doi.org/ 10.1016/j.jasrep.2017.12.017.

Speth, J. D., \& Clark, J. L. (2006). Hunting and overhunting in the Levantine Late Middle Palaeolithic. Before Farming, 3. https://doi.org/10.3828/bfarm.2006.3.1.

Staesche, U. (1983). Aspects of the life of Middle Paleolithic hunters in the N.W. German Lowlands, based on the site Salzgitter-Lebenstedt. In J. Clutton-Brock \& C. Grigson (Eds.), Animals and Archaeology: Hunters and Their Prey (pp. 173-181). BAR International Series.

Stewart, M., Carleton, W. C., \& Groucutt, H. S. (2021). Climate change, not human population growth, correlates with Late Quaternary megafauna declines in North America. Nature Communications, 12. https://doi.org/10.1038/s41467-021-21201-8.

Stiles, D. (1992). The hunter-gatherer "revisionist" debate. Anthropology Today, 8(2), 13-17.

Stiles, D. (2001). Hunter-gatherer studies: The importance of context. African study monographs. Supplementary Issue, 26, 41-65. https://doi.org/10.14989/68408.

Strömberg, C. A. E., Dunn, R. E., Crifò, C., \& Harris, E. B. (2018). Phytoliths in paleoecology: analytical considerations, current use, and future directions. In D. A. Croft, D. F. Su, \& S. W. Simpson (Eds.), Methods in Paleoecology (pp. 235-287). Springer International Publishing.

Sugita, S. (2007a). Theory of quantitative reconstruction of vegetation I: Pollen from large sites REVEALS regional vegetation composition. The Holocene, 17(2), 229-241. https://doi.org/10. $1177 / 0959683607075837$.

Sugita, S. (2007b). Theory of quantitative reconstruction of vegetation II: All you need is LOVE. The Holocene, 17(2), 243-257. https://doi.org/10.1177/0959683607075838.

Sugita, S., Gaillard, M.-J., \& Broström, A. (1999). Landscape openness and pollen records: A simulation approach. The Holocene, 9, 409-421.

Surovell, T. A., \& Pelton, S. R. (2016). Spatio-temporal variation in the preservation of ancient faunal remains. Proceedings of the Royal Society, 12. https://doi.org/10.1098/rsbl.2015.0823.

Surovell, T., Waguespack, N., \& Brantingham, P. J. (2005). Global archaeological evidence for proboscidean overkill. PNAS, 102(17), 6231-6236. www.pnas.org/cgi/doi/10.1073/pnas.0501947102.

Svenning, J.-C. (2002). A review of natural vegetation openness in north-western Europe. Biological Concervation, 104, 133-148.

Swift, J. A., Bunce, M., Dortch, J., Douglass, K., Faith, J. T., Fellows Yates, J. A., et al. (2019). Micro methods for megafauna: Novel approaches to Late Quaternary extinctions and their contributions to faunal conservation in the Anthropocene. BioScience, 69(11), 877-887. https://doi.org/10.1093/ biosci/biz105.

Thompson, J. C., Wright, D. K., \& Ivory, S. J. (2020). The emergence and intensification of early huntergatherer niche construction. Evolutionary Anthropology: Issues, News, and Reviews, 30, 17-27. https://doi.org/10.1002/evan.2187.

Thompson, J. C., Wright, D. K., Ivory, S. J., Choi, J. H., Nightingale, S., Mackay, A., et al. (2021). Early human impacts and ecosystem reorganization in southern-central Africa. Science. Advances, 7(19). https://doi.org/10.1126/sciadv.abf9776.

Toepfer, V. (1958). Steingeräte und Palökologie der mittelpleistozänen Fundstelle Rabutz bei Halle (Saale). Jahresschrift für Mitteldeutsche Vorgeschichte, 41-42, 140-177.

Trondman, A.-K., Gaillard, M.-J., Mazier, F., Sugita, S., Fyfe, R., Nielsen, A. B., et al. (2015). Pollenbased quantitative reconstructions of Holocene regional vegetation cover (plant-functional types and land-cover types) in Europe suitable for climate modelling. Global Change Biology, 21, 676697. https://doi.org/10.1111/gcb.12737.

Tunno, I., \& Mensing, S. A. (2017). The value of non-pollen palynomorphs in interpreting paleoecological change in the Great Basin (Nevada, USA). Quaternary Research. https://doi.org/10.1017/qua. 2017.8 . 
Twiss, P. C. (2001). A curmudgeon's view of grass phytolithology. In J. D. Meunier \& F. Colin (Eds.), Phytoliths: Applications in Earth Sciences and Human History (pp. 119-128). Zeitlinger Publishers.

Vachula, R. S., \& Richter, N. (2018). Informing sedimentary charcoal-based fire reconstructions with a kinematic transport model. The Holocene, 28(1), 173-178. https://doi.org/10.1177/0959683617 715624.

Vachula, R. S., Russell, J. M., Huang, Y., \& Richter, N. (2018). Assessing the spatial fidelity of sedimentary charcoal size fractions as fire history proxies with a high-resolution sediment record and historical data. Palaeogeography, Palaeoclimatology, Palaeoecology, 508, 166-175. https://doi.org/ 10.1016/j.palaeo.2018.07.032.

Wang, Y., Pedersen, M. W., Alsos, I. G., De Sanctis, B., Racimo, F., Prohaska, A., et al. (2021). Late Quaternary dynamics of Arctic biota from ancient environmental genomics. Nature. https://doi. org/10.1038/s41586-021-04016-x.

Warren, G., Davis, S., McClatchie, M., \& Sands, R. (2014). The potential role of humans in structuring the wooded landscapes of Mesolithic Ireland: A review of data and discussion of approaches. Vegetation History and Archaeobotany, 23(5), 629-646. https://doi.org/10.1007/s00334-013-0417-z.

Wassenaar, L. I. (2008). An introduction to light stable isotopes for use in terrestrial animal migration studies. In K. A. Hobson \& L. I. Wassenaar (Eds.), Tracking animal migration with stable isotopes (pp. 21-44). Academic Press.

Waters, C. N., Zalasiewicz, J., Summerhayes, C., Barnosky, A. D., Poirier, C., Gałuszka, A., et al. (2016). The Anthropocene is functionally and stratigraphically distinct from the Holocene. Science, 351(6269). https://doi.org/10.1126/science.aad2622.

Whelan, R. J. (1995). The ecology of fire. Cambridge University Press.

Wißing, C., Rougier, H., Baumann, C., Comeyne, A., Crevecoeur, I., Drucker, D. G., et al. (2019). Stable isotopes reveal patterns of diet and mobility in the last Neandertals and first modern humans in Europe. Scientific Reports, 9. https://doi.org/10.1038/s41598-019-41033-3.

Woldring, H., Schepers, M., Mendelts, J., \& Fens, R. (2012). Camping and foraging in Boreal hazel woodland - The environmental impact of Mesolithic huntergatherers near Groningen, the Netherlands. In M. J. L. T. N. Terberger, R. N. E. Barton, \& M. Street (Eds.), A mind set on flint. Studies in honour of Dick Stapert (pp. 381-392). Barkhuis Publishing.

Wolf, E. R. (2010). Europe and the people without history. University of California Press.

Woodburn, J. (1980). Hunters and gatherers today and reconstruction of the past. In E. Gallner (Ed.), Soviet and Western Anthropology (pp. 95-117). Duckworth.

Wrangham, R. (2009). Catching fire. How cooking made us human. Profile books.

Zagwijn, W. H. (1989). Vegetation and climate during warmer intervals in the Late Pleistocene of western and central Europe. Quaternary International, 3-4, 57-67. https://doi.org/10.1016/1040-6182(89) 90074-8.

Zalasiewicz, J., Waters, C. N., Williams, M., Barnosky, A. D., Cearreta, A., Crutzen, P., et al. (2015). When did the Anthropocene begin? A mid-twentieth century boundary level is stratigraphically optimal. Quaternary International, 383, 196-203. https://doi.org/10.1016/j.quaint.2014.11.045.

Zalasiewicz, J., Waters, C. N., Williams, M., \& Summerhayes, C. (Eds.). (2019). The Anthropocene as a geological time unit. Cambridge University Press.

Zeder, M. A., Emshwiller, E., Smith, B. D., \& Bradley, D. G. (2006). Documenting domestication: The intersection of genetics and archaeology. Trends in Genetics, 22(3), 139-155. https://doi.org/10. 1016/j.tig.2006.01.007.

Zhang, J., Lu, H., Wu, N., Li, F., Yang, X., Wang, W., et al. (2010). Phytolith evidence for rice cultivation and spread in Mid-Late Neolithic archaeological sites in central North China. BOREAS. An International Journal of Quaternary Research. https://doi.org/10.1111/j.1502-3885.2010.00145.x.

Zurro, D., Madella, M., Briz, I., \& Vila, A. (2009). Variability of the phytolith record in fisher-huntergatherer sites: An example from the Yamana society (Beagle Channel, Tierra del Fuego, Argentina). Quaternary International, 193(1-2), 184-191. https://doi.org/10.1016/j.quaint.2007.11.007.

Zvelebil, M. (1994). Plant use in the Mesolithic and its role in the transition to farming. Proceedings of the Prehistoric Society, 60, 35-74.

Publisher's Note Springer Nature remains neutral with regard to jurisdictional claims in published maps and institutional affiliations. 


\section{Authors and Affiliations}

Anastasia Nikulina ${ }^{1}$ (D) $\cdot$ Katharine MacDonald $^{1}$ (D) . Fulco Scherjon ${ }^{1}$ (D) . Elena A. Pearce ${ }^{2}$ (D) Marco Davoli ${ }^{2}(\mathbb{D})$. Jens-Christian Svenning ${ }^{2}$ (D) Emily Vella ${ }^{3}$ - Marie-José Gaillard ${ }^{4}$ (D) Anhelina Zapolska ${ }^{5}$ (D) Frank Arthur ${ }^{6}$. Alexandre Martinez ${ }^{7}$ (D) Kailin Hatlestad ${ }^{3}$. Florence Mazier ${ }^{8}$.D . Maria Antonia Serge ${ }^{8} \cdot$ Karl-Johan Lindholm $^{3}$ (D) Ralph Fyfe $^{9}$ (D) Hans Renssen $^{6}$ (D) Didier M. Roche ${ }^{5,10}$ (D) Sjoerd Kluiving ${ }^{7,11^{(D)}}$. Wil Roebroeks ${ }^{1}$ (iD

$\triangle$ Anastasia Nikulina nikulina1302@gmail.com; a.nikulina@arch.leidenuniv.nl

1 Faculty of Archaeology, Department of World Archaeology, Human Origins Group, Leiden University, Leiden, The Netherlands

2 Center for Biodiversity Dynamics in a Changing World (BIOCHANGE) \& Section for Ecoinformatics and Biodiversity, Department of Biology, Aarhus University, Aarhus, Denmark

3 Department of Archaeology and Ancient History, Uppsala University, Uppsala, Sweden

4 Department of Biology and Environmental Science, Linnaeus University, Kalmar, Sweden

5 Faculty of Science, Department of Earth Sciences, Vrije Universiteit Amsterdam, Amsterdam, The Netherlands

6 Department of Natural Sciences and Environmental Health, University of South-Eastern Norway, B $\emptyset$, Norway

7 Faculty of Humanities, Department of Art and Culture, History, Antiquity, Vrije Universiteit Amsterdam, Amsterdam, The Netherlands

8 Department of Environmental Geography, CNRS UMR GEODE 5602, University Toulouse Jean Jaurès, Toulouse, France

9 School of Geography, Earth and Environmental Sciences, University of Plymouth, Plymouth, UK

10 Laboratoire des Sciences du Climat et de l'Environnement, LSCE/IPSL, CEA-CNRS-UVSQ, Université Paris-Saclay, Gif-sur-Yvette, France

11 Faculty of Science, Institute for Environmental Studies (IVM), Vrije Universiteit Amsterdam, Amsterdam, The Netherlands 